\title{
Flash floods mitigation and assessment of groundwater possibilities using remote sensing and GIS applications: Sharm El Sheikh, South Sinai, Egypt
}

\author{
Mohamed Yousif and Hussien M. Hussien
}

\begin{abstract}
Background: In arid and hyper arid regions, flash floods directly affect human life and ecosystem balance through soil erosion and sediment exchange between different watersheds. The present study provides an integrated approach using remote sensing and geophysical data, multiple thematic layers, and field investigations to mitigate the flash flood hazard and explore the groundwater potentiality in Sharm El Sheikh area, Egypt, where devastating flash flood hazards and shortage in water supply are critical problems against the development of the touristic city.

Results: A new flood hazard index (FHI) is introduced using the morphometric parameters and multiple thematic layers for the investigated hydrographic basins. The FHI ranges between 55.2 (low) and 73 (very high). The resulted surface runoff from a single event $(59 \mathrm{~mm} /$ day) reached up to $7.96 \mathrm{~mm}$ while the total runoff volume reached up to $20.23\left(10^{6}\right) \mathrm{m}^{3}$ representing about $13.5 \%$ of the total rainfall. Hydrogeologically, the Miocene sediments represent the main aquifer, which is cut by four recognized faults providing opportunities for enhanced groundwater recharge. The integrated geophysical datasets (aeromagnetic and vertical electrical sounding) and borehole data indicate that the subsurface sedimentary succession reaches up to $200 \mathrm{~m}$ of Quaternary and Miocene sediments.

Conclusions: The present study introduces a comprehensive system to mitigate floods and increase the opportunity of groundwater recharge that could protect and enhance the environment under arid conditions. The presented approach can be applied in any arid and hyper arid regions with the same conditions.
\end{abstract}

Keywords: Hydrogeology, Surface runoff, Flood hazard index, Groundwater, Recharge mechanism

\section{Introduction}

Climate change led to a global increase of the earth surface temperature and decrease of the precipitation amounts, which consequently created stress on groundwater exploration and exploitation (IPCC 2014). The excessive demand for freshwater supplies in arid and hyper-arid regions is steering the governments to look for alternative water resources. Egypt, as one of the

\footnotetext{
* Correspondence: yousif_mohamed80@daad-alumni.de

The original version of this article was revised: we were notified that formulas 3 and 4 are incomplete (cut off) in the PDF.

Geology Department, Desert Research Center, El Mataryia, P.O.B. 11753, Cairo,
} Egypt

\section{Springer Open}

countries that fall in the hyper arid belt (i.e., aridity index below 0.03; UNESCO 1979), is suffering from water shortage and scarcity of modern precipitation where the average annual rainfall rarely exceeds $200 \mathrm{~mm}$ (Allama et al. 2002). In spite of the paucity of rainfall in Egypt, occasional flash flood events are recorded in the Sinai Peninsula and the Eastern Desert of Egypt occurring once every 3 to 4 years in the Eastern Desert but more repeatedly in Sinai (Naim 1995; Gheith and Sultan 2002; Moawad et al. 2016). According to IFRC (2010), the areas of Sharm El Sheikh and Nuweiba that are located at the south section of the Sinai Peninsula have been severely hit by flash floods (Fig. 1). These torrential

(c) The Author(s). 2020, corrected publication 2020 Open Access This article is licensed under a Creative Commons Attribution 4.0 International License, which permits use, sharing, adaptation, distribution and reproduction in any medium or format, as long as you give appropriate credit to the original author(s) and the source, provide a link to the Creative Commons licence, and indicate if changes were made. The images or other third party material in this article are included in the article's Creative Commons licence, unless indicated otherwise in a credit line to the material. If material is not included in the article's Creative Commons licence and your intended use is not permitted by statutory regulation or exceeds the permitted use, you will need to obtain permission directly from the copyright holder. To view a copy of this licence, visit http://creativecommons.org/ licenses/by/4.0\%. 


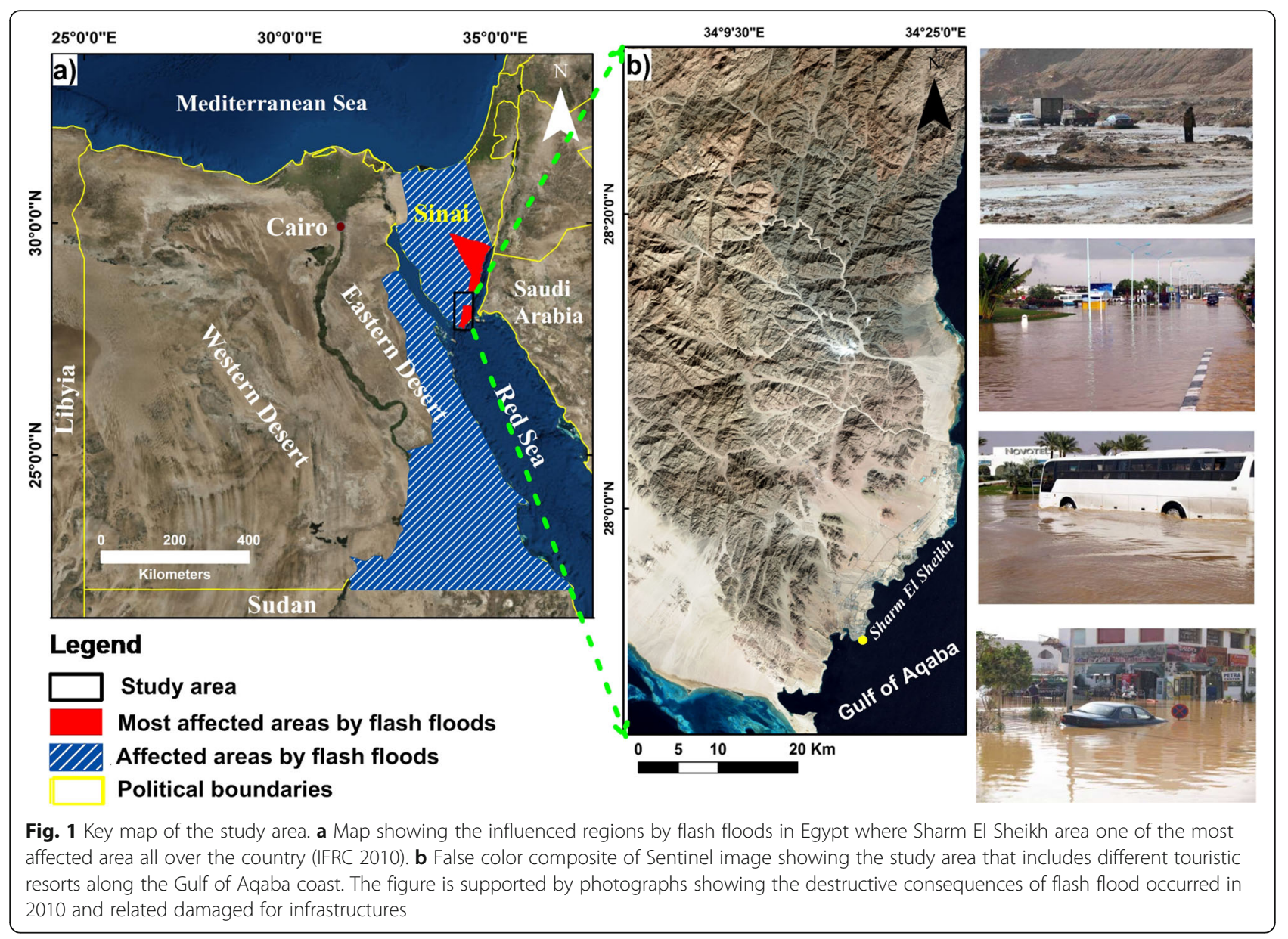

floods have seriously affected the infrastructure of several communities in the Sinai Peninsula (e.g., the touristic resorts and nature parks of Sharm El Sheikh, Nuweiba and Taba) which had temporarily blackout. Moreover, the main communication center of Sharm El Sheikh has been severely destroyed and the international airport of the city was closed for several hours after the floods damaged its ceiling. On the other hand, floods are considered as precious and valuable renewable source of fresh water in arid environments. One of the major challenges that faces Egypt and most of the arid countries is how to manage and develop their natural resources to meet the needs of their growing communities (El Raey 1998). Furthermore, despite of the crucial needs of freshwater supplies in Sharm El Sheikh area, a comprehensive study for assessing the hydrogeologic setting and recharge mechanism is still not conducted yet.

Remote sensing data along with Geographic Information System (GIS) technologies are helpful tools and widely used in producing spatial decision support system maps (DSSM) (Das et al. 2017, 2018). Also, it provides an easy way to prepare different types of maps ( e.g., geomorphologic, lithologic, and structural [i.e., shear zones, faults, fractures, lineaments and folds]) especially at regional scales due to their multi-spectral capability and synoptic coverage (Siegal and Gillespie 1980; Drury 1987). Furthermore, GIS applications have emerged as powerful tools in assessing and monitoring the natural hazards such as flashfloods, landslides, and earthquakes (Das et al. 2017, 2018). Additionally, remote sensing data have been vastly used for better understanding the water cycle as well as the surface watergroundwater interaction in arid to hyper-arid environments (Sultan et al. 2008; Milewski et al. 2009; Abotalib et al. 2016; Abotalib et al. 2019). Moreover, the data acquired from the geophysical investigations (e.g., aeromagnetic survey and vertical electrical sounding) are considered as another type of remote sensing data that help in detecting hidden subsurface structures. Therefore, a preliminary geophysical investigation was necessary to delineate the subsurface structures (i.e., shallow and deep-seated faults) in the study area. The aeromagnetic data provides an effective tool for investigating the deep-seated structures along regional scales (Spector and Grant 1970). Many studies have used aeromagnetic data to detect the subsurface structures in Egypt (Bayoumi and Boctor 1970; Said and Ahmed 1990; Meshref et al. 1992; Hussien et al. 2017). Also, 
morphometric analysis of drainage basins represents an essential step for determining the water recharge sits, runoff modeling, watershed delineation, and groundwater prospecting mapping (Magesh et al. 2011; Thomas et al. 2012; Abotalib and Mohamed 2013). Furthermore, the morphometric analysis provides a quantitative watershed description to illustrate the initial slope or variations in the rock hardness, structural controls, geomorphic and geological history of watersheds (Strahler 1964; Clarke 1966).

In this manuscript, we apply a cost effective, multidisciplinary research approach including integration of remote sensing and geophysical datasets (i.e., aeromagnetic and vertical electrical sounding), thematic layers produced from Geographic Information System (GIS) and field investigation to assess the groundwater potentiality and mitigate the flash flood hazards in coastal areas in arid environments. Specifically, this study aims to (1) investigate the flash flood hazards and suggest controlling systems to reduce their destructive effects; (2) assess the recharge sites and best locations for groundwater occurrences in the study area; (3) suggest potential sites for groundwater exploration based on the obtained results; (4) create a conceptual model to illustrate the recharge mechanism of the aquifers. Finally, this study provides recommendations that could potentially help in the development plans of Sharm El Sheikh area, and can be applied in similar arid regions elsewhere.

\section{Site description}

Sharm El Sheikh city is one of the most fascinating touristic resorts along the Red Sea Coast that is suffering from a shortage in the water supply (water supply-demand gap) where the fresh water is imported from El Tor city that is located about $100 \mathrm{~km}$ to the west of Sharm El Sheikh (Ahmed et al., 2014, b; El Dien 2016). The area of study (surface area, $1866.73 \mathrm{~km}^{2}$ ) is located at the southernmost part of the Sinai Peninsula (Long. $33.9983 \mathrm{E}$ and 34.4476 $\mathrm{E}$ and Lat. $27.7186 \mathrm{~N}$ and $28.5218 \mathrm{~N}$ ). It is bound by volcano-sedimentary rocks that are part of the Neoproterozoic Arabian Nubian Shield (ANS) (550-900 Ma) from the west and the Gulf of Aqaba from the East (Greenwood et al. 1980; David, 1984) (Fig. 1). The area of study represents $20 \%$ of the total surface area of the Gulf of Aqaba hydrographic basin (surface area, $8927 \mathrm{~km}^{2}$ ) which consists of a network of minor valleys that cut through the ANS and join into main valleys that finally drain into the Gulf of Aqaba. These drainage networks (16 basins) harvest the rainwater of the occasional events as a surface runoff in the main streams and as a recharging source for the shallow groundwater aquifers in the study area. Evidences from chemical and isotopic analysis $\left(\delta^{18} \mathrm{O}\right.$ and $\left.\delta^{2} \mathrm{H}\right)$ of groundwater samples from the Eastern Desert of Egypt and Sinai Peninsula support that the groundwater of shallow alluvial and Nubian sandstone aquifers are currently receiving recharge from modern precipitation and flash floods with modern and evaporated isotopic signature (Sultan et al. 2000; Hussien et al. 2017).

Geologically, Sharm El-Sheikh area encompasses many lithologic units that range in age from Precambrian to Quaternary (Fig. 2, EGSMA 1994). The Precambrian basement complex (ANS) forms a highly rugged granitic mountains facing the Gulf of Aqaba (Said 1962; Aggour et al. 2000). These rock units are composed mainly of older and younger granites (Said 1962; Bentor 1985; Stern 1994; Abu-Alam and Stüwe 2009) and underlie a thick sedimentary succession that ranges in age from Neogene to Quaternary. This succession include (from base to tope) the Rudays Formation of lower Miocene age, Ras Muhamed Formation of Pliocene age, and Quaternary alluvium deposits (EGSMA 1994). According to Shata (1969) and Abdeltawab (2012), the Miocene succession is bisected into two units, upper and lower units with a total thickness of $80.5 \mathrm{~m}$ and $90 \mathrm{~m}$, respectively. The lower Miocene unit is formed mainly of clastic facies (e.g., coarse grained sandstone, red shale with lenses of conglomerate, and manganese oxides) while the upper Miocene unit formed mainly of non-clastic facies (e.g., limestone, dolomitic limestone intercalated with coarse grained sandstone and shale) (Shata 1969). While Ras Muhamed Formation composed mainly of highly fossiliferous reefal limestone of Pliocene age occupying some parts of the coastal area between Ras Nusrani and Sharm El Sheikh area (EGSMA 1994). The Quaternary alluvium deposits are formed of the weathered product of the Precambrian igneous rocks and Miocene deposits filling the courses of the hydrographic drainage network (El Manakhly et al. 1997). These sediments have great potentiality to store and transmit considerable amounts of groundwater.

In general, the area under investigation falls within arid to hyper-arid belt and characterized by long hot, rainless summer, and mild winter (Arnous and Green 2011). The average monthly temperature is $17{ }^{\circ} \mathrm{C}$ in January and 32 ${ }^{\circ} \mathrm{C}$ in August, while the relative humidity record 32\% in July and 48\% in December (El-Refeai 1992; Abd Allah 1999). In spite of the low average annual precipitation in the Sharm El sheikh area, $25 \mathrm{~mm} /$ year (El-Refeai 1992), flash floods take place as a result of heavy showers in a short duration. These flash storms represent the main sources of fresh water that recharge the shallow aquifers in the Gulf of Aqaba hydrographic basins (Himida 1997; Eissa et al. 2013), which are estimated by 5 to $20 \%$ of the total annual precipitation and flood storms (Desconnets et al. 1997; Wheater et al. 2010).

\section{Methods}

Processing and analysis of remote sensing and GIS data sets

In the present study, all collected data were co-registered to unified projection (Datum; WGS 84, Universal Transverse 


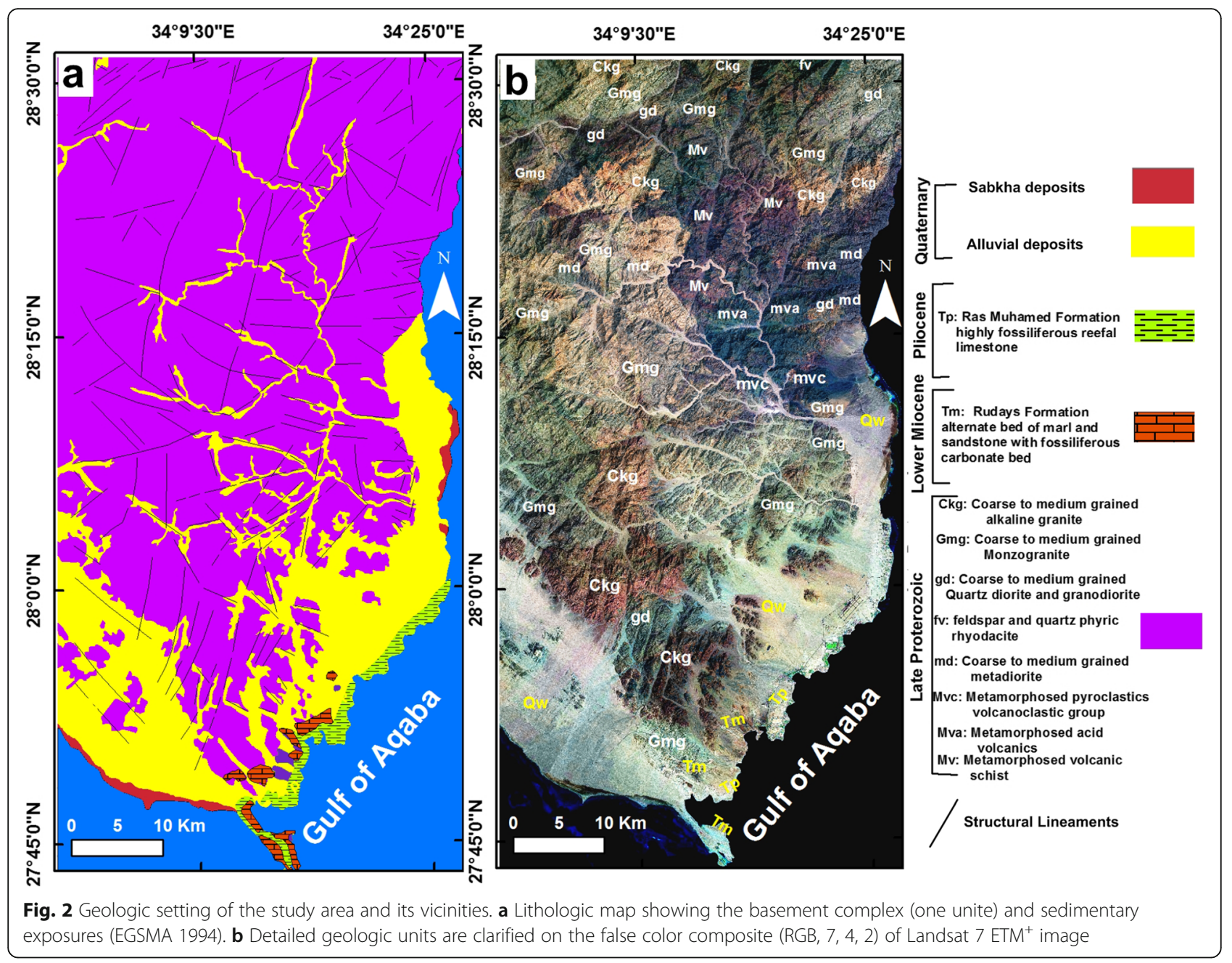

Mercator (UTM) zone; 36 North) in Arc GIS program, version 10.4 for further correlation. The remote sensing data sets sources and processing include the following: (1) false color composite (RGB; 4, 3, 2) of Sentinel-2 image was used as a base map for the study area and also to illustrate the location of suggested warning system for flash floods mitigation (2 scenes; spatial resolution $10 \mathrm{~m}$; source: USGS website $\left.^{1}\right)$. The Sentinel-2 images were combined into a single mosaic covering the study area using the application of ERDAS IMAGINE version 14. (2) The Digital Elevation Model (DEM) of Shuttle Radar Topographic Mission (SRTM) (2 scenes; spatial resolution: $30 \mathrm{~m}$; sources: USGS website ${ }^{1}$ ) were assembled in a single mosaic using ARC GIS application version 10.4 to cover the area of Sharm El Sheikh and vicinities. Then both mosaics of the Sentinel-2 images and SRTM DEM were imported to ESRI Arc Scene version 10.4 to create a $3 \mathrm{D}$ view for the study area. The produced 3D view was used to create conceptual model for the expected recharging mechanism from the flash floods that strike the study area. (3) False color composite (RGB; 7, 4, 2) of Landsat 7 Enhanced Thematic Mapper plus
(ETM+; 2 scene; spatial resolution: 30 m; USGS website ${ }^{1}$ ) was assembled into a single mosaic using the application of ENVI version 5.1. Then the mosaic of SRTM and ETM+ were imported into ESRI Arc Scene application to create a 3D view for Sharm El Sheikh for better visualization of the landscape and to illustrate the main landform and geomorphologic features in the study area. (4) Landsat 7 (ETM+; RGB: 7, 4, 2) $14.5 \mathrm{~m}$ pan-sharpened image was produced using Arc GIS application to create a high spatial resolution image. Then this image was used with the help of the geologic maps to identify the rock units in the study area especially the basement rocks and the Quaternary deposits. (5) Hillshade relief of SRTM DEM $30 \mathrm{~m}$ spatial resolution was used with Landsat 8 image (band combination $7,5,3$ ) in the Arc GIS software to extract the structural lineaments (fault and/or fractures) used in this study. The structural lineaments are traced manually from the hill shaded map and used to create the rose diagram that provides more clarification of the lineaments alignment. (6) Band combination of Landsat 8 (OLI) ratio image (e.g., 4/3, 6/2, and 7/4 in RGB) was created. 
http://www.earthexplorer.usgs.gov (accessing date 2018)

${ }^{2}$ http://www.planet.com./explorer/(accessing date 2018)

The ratios of bands $4 / 3,6 / 2$, and $7 / 4$ in Landsat 8 are distinctive ratios for lithologic discrimination between different rock types based on their mineralogical and chemical compositions. Such ratios have been used in semi-arid to hyper-arid region in geologic mapping and visualizing structural lineaments (Mwaniki et al. 2015). (7) Principal component analysis (PCA) is a simple method used to enhance the multispectral Landsat image prior to the visual interpretation or being used as a primary stage before image classification (Chae et al. 1997). The PCA images were created to produce non-correlated output data and to separate noise in specific bands. Starting with the original Landsat image, six bands of PCA were extracted, where PCA 1, 2, and 3 represent the least noise component. The band combination of PCA 1, 2, and 3 have been used in lithologic discrimination between different rock units in this study. (8) The stream network and watershed boundaries were extracted and created from SRTM DEMs data following the method of the D8 flow algorithm of Jenson and Domingue (1988). Furthermore, multi thematic layers have been created from the DEMs including flow direction, slope map, and Hillshade relief map. (9) False color composite (RGB:321) of planet satellite image (5 scene; spatial resolution $3 \mathrm{~m}$; source a planet explorer website ${ }^{2}$ ) was used to illustrate the accurate locations of the proposed sites for groundwater exploration in the study area.

\section{Morphometric analyses}

Morphometric analysis of catchment areas and stream networks have a great contribution to understanding the hydrogeologic attitude of drainage basins and reflect the existing geomorphologic, geologic, structural, and climatic conditions (Ansari et al. 2012). The measurement of the morphometric parameters (i.e., linear, areal, and relief aspects of the watersheds) have been calculated using the Arc GIS software. The adopted method for calculating the morphometric parameters have been shown in Table 1 . The quantitative morphometric analysis of the studied basins led to the determination of a total of 21 morphometric parameters. The information provided from these parameters have strong relevance in evaluating the flood hazard with the surface hydrology in the studied catchment area.

\section{Producing equations for estimating flood hazard index (FHI)}

Based on climatic, geologic, and geomorphologic conditions of the study area, 12 morphometric parameters were selected based on their relevance to the strength of flash flood events. These parameters include the area of the basin (A), slope index (SI), drainage density (D), drainage frequency $(\mathrm{F})$, shape index (Ish), ruggedness number $(\mathrm{Rn})$, texture ratio $(\mathrm{Rt})$, area of the alluvial deposits (Av), weighted mean bifurcation ratio (WMRB), structure lineament density (SLD), length of overland flow (Lo), and sinuosity index (Si). According to the nature of each parameter and its influence on the flood hazard, they were subdivided into two groups; the first group shows the parameters with direct proportional relation with the FHI and includes A, SI, D, F, Ish, Rn, and Rt (Eq. 1). The second group includes parameters that have an inverse relation with the FHI and includes Av, WMRB, Lo, SLD, and Si (Eq. 2).

$$
P_{p} \alpha \mathrm{FHI}
$$

where $P_{p}$ represents the morphometric parameters that are directly proportional to the $\mathrm{FHI}$ and $p$ is directly proportional relationship.

$$
P_{i} \alpha 1 / \text { FHI }
$$

where $P_{i}$ denotes the morphometric parameters that are inversely proportional to the FHI, $i$ is inversely relationship.

Different weights (w) were proposed for each parameter based on their sharing effect on the strength of the flood hazard degree. These proposed weights were used in Eqs. (3) and (4) to estimate the FHI for each parameter in each basin.

$$
\begin{aligned}
& \mathrm{FHI}_{p}= \\
& {\left[\text { value of } P_{p} \text { in basin } /\right.} \\
& \text { maximum recorded value of the parameter in all basins }] \times \mathrm{W}
\end{aligned}
$$

In order to determine the flood hazard index for each of the studied basins relative to each other, the summation of the 12 flood hazard index of the directly proportional and inversely parameters were calculated in each basin as shown in Eq. (5).

$$
\mathrm{FHI}_{\text {total }}(\text { for each basin })=\sum \mathrm{FHI}_{p}+\mathrm{FHI}_{i}
$$

The obtained values of FHI of each basin categorize the studied basins according to their flood strength in ascending classes into four classes that express the hazard degrees: low, moderate, high, and very high according to the method described by Aggour et al. (1999). 
Table 1 Methodology used for calculation of the morphometric parameters

\begin{tabular}{|c|c|c|c|c|c|}
\hline $\begin{array}{l}\text { Serial } \\
\text { No. }\end{array}$ & & Parameters & Units & Method of calculations & References \\
\hline 1 & Linear & Sum of all stream numbers (S Nu) & & $\begin{array}{l}\text { Counted using Arc GIS software where (Nu is the number of } \\
\text { order } \mathrm{u} \text { ) }\end{array}$ & \\
\hline 2 & & Sum of all stream lengths (S Lu) & $\mathrm{Km}$ & Measured from DEM using Arc GIS software & \\
\hline 4 & & Bifurcation ratio $(\mathrm{Rb})$ & & $\mathrm{Rb}=\mathrm{Nu} / \mathrm{Nu}+1$ & Horton (1945) \\
\hline 5 & & $\begin{array}{l}\text { weighted mean bifurcation ratio } \\
\text { (WMRb) }\end{array}$ & & $W M R b=\sum\left[\left(R^{\prime} u_{:} u_{+1}\right) *\left(N u+N u_{+1}\right)\right] / \Sigma N$ & Strahler (1953) \\
\hline 6 & & Valley length (VL) & $\mathrm{Km}$ & Measured from DEM using Arc GIS software & \\
\hline 7 & & Basin length (LB) & $\mathrm{Km}$ & Measured from DEM using Arc GIS software & \\
\hline 3 & & Sinuosity index (Si) & $\mathrm{Km}$ & $\mathrm{Si}=$ sinuosity $(\mathrm{VL} / \mathrm{LB})(\mathrm{km})$. & $\begin{array}{l}\text { Gregory and Walling } \\
\text { (1973) }\end{array}$ \\
\hline 8 & Areal & Drainage frequency $(F)$ & $\mathrm{km}^{-2}$ & $\mathrm{~F}=\Sigma \mathrm{N}_{u} / A$ & Horton (1945) \\
\hline 9 & & $\begin{array}{l}\text { Area of alluvium deposits in basin } \\
\text { (Av) }\end{array}$ & $\mathrm{km}^{2}$ & $\begin{array}{l}\text { Measured from DEM using Arc GIS software with geologic } \\
\text { maps }\end{array}$ & \\
\hline 10 & & Drainage density (D) & $\mathrm{km}^{-1}$ & $\mathrm{D}=\Sigma \mathrm{L}_{u} / \mathrm{A}$ & Horton (1945) \\
\hline 11 & & Perimeter (P) & $\mathrm{Km}$ & Measured from DEM using Arc GIS software & \\
\hline 12 & & Area of the basin $(A)$ & $\mathrm{Km}^{2}$ & Measured from DEM using Arc GIS software & \\
\hline 13 & & Elongation ratio $(\mathrm{Re})$ & & $\operatorname{Re}=2(\mathrm{~A} / \Pi)^{0.5} / \mathrm{LB}$ & Schumm (1956) \\
\hline 14 & & Circularity ratio $(\mathrm{Rc})$ & & $\mathrm{Rc}=4 \Pi \mathrm{A} / \mathrm{P}^{2}$ & Miller (1953) \\
\hline 15 & & Length of overland flow (Lo) & $\mathrm{Km}$ & $\mathrm{LO}=1 / 2 \mathrm{D}$ & Horton (1945) \\
\hline 16 & & Texture Ratio (Rt) & $\mathrm{Km}^{-1}$ & $\mathrm{Rt}=\Sigma \mathrm{Nu} / \mathrm{p}$ & Horton (1945) \\
\hline 17 & & shape index (Ish) & & $\mathrm{Ish}=1.27 . \mathrm{A} / \mathrm{LB}^{2}$ & Hagget (1956) \\
\hline 18 & Relief & Relief (R) & $\mathrm{m}$ & Measured from DEM using Arc GIS software & \\
\hline 19 & & Slope index (SI) & & $\mathrm{SI}=\mathrm{E} 85-\mathrm{E} 10 / 0.75 \mathrm{VL}$ & \\
\hline 20 & & Relief ratio $(\mathrm{Rr})$ & & $\mathrm{Rr}=\mathrm{R} / \mathrm{LB}$ & Schumm (1956) \\
\hline 21 & & Ruggedness number (Rn) & & $\mathrm{Rn}=\mathrm{DR}$ & Melton (1957) \\
\hline
\end{tabular}

\section{Estimation of surface runoff}

The curve number $(\mathrm{CN})$ is a hydrologic parameter used to express about surface water runoff potential for an area. The current study used the curve number which was introduced by USDA-SCS (1986) to the soil and land use of the studied basins. The runoff volume estimation is expressed mathematically as follows (USDASCS 1972 and 1986):

$$
\begin{aligned}
& \mathrm{Q}(\text { surface runoff })=(P-\mathrm{Ia}) 2 /(P+0.8 S) \text { for } P \\
& >0.2 S \\
& \mathrm{Ia}=0.2 S
\end{aligned}
$$

A dimensional curve number $\mathrm{CN}$ is defined such as 0 $<\mathrm{CN}>100$

$$
\mathrm{S}=(25400 / \mathrm{CN})-254
$$

where $P$ is the total rainfall, Ia is the initial abstraction, and $S$ is the potential maximum retention. The total runoff volume $(\mathrm{Qv})$ for an area $(\mathrm{A})$ is calculated through the next equation:

$$
\mathrm{Qv}(\mathrm{m} 3)=Q(\mathrm{~m}) \times \mathrm{A}\left(\mathrm{m}^{2}\right)
$$

The soil hydrologic group of the studied basin was classified as (HSG-B: moderately low runoff potential where $50-90 \%$ sand and $10-20 \%$ clay) according to Global Hydrologic Soil Groups. These data are accessed through the Oak Ridge National Laboratory (ORNL DAAC 2017) Distributed Active Archive Center (DAAC) for Curve Number-Based Runoff Modeling by using the Geospatial Data Visualization tool (Ross et al. 2018).

\section{Geophysical data sources}

The geophysical data was obtained from different sources in an attempt to identify the subsurface setting where it includes aeromagnetic data (reduced to pole) and vertical electrical sounding (VES). A brief description of the sources of the geophysical data can be expressed as follows:

1) Reduced to pole (RTP) aeromagnetic data 
The RTP are provided through the work of (Saleh and Saleh 2012) where the south Sinai area is extracted from the 2-arc-min resolution Earth Magnetic Anomaly (nT) grid (EMAG2), (Maus et al. 2007 and Maus et al. 2009). EMAG2 is available at: http://geomag.org/models/ EMAG2 for permanent archive, and at: http://earthref. org/cgi-bin/er.cgi?s=erda.cgi? $n=970$. The EMAG2 has been compiled from satellite, ship, and airborne magnetic measurements and has a significant update of previous candidate grid for the World Digital Magnetic Anomaly Map where the resolution has been improved from 3-arc min to 2-arc min, and the altitude has been reduced from 5 to $4 \mathrm{~km}$ above the geoid. The extracted data $(x, y, z)$ was imported to the Oasis Montaj TM package (version 7.1, 2010) to apply the 3D Euler deconvolution solution.

2) 3D Euler deconvolution solution from RTP data

This map is obtained from (Saleh and Saleh 2012) based on the Euler's equation that was defined by Reid et al. (1990). A value of 0.5 was selected as a structural index to locate the possible magnetic contacts from the digitized RTP magnetic data.

\section{3) A deduced structural map}

This map was derived from the 3D Euler deconvolution solution where all major tectonic features could be observed.

\section{4) Vertical electrical sounding (VES)}

In the present study, 2 VES profiles from Abdallah and El Hefnawy (2002) were used to clarify the subsurface succession where they provided data for the creation of the schematic cross sections.

\section{Results}

The current research represents a multi-disciplinary approach that is based on data from different sources. The obtained results can be summarized as follows:

\section{Landforms demarcation}

Based on the analyses of DEM and Landsat images, the study area can be subdivided to 4 main landforms: basement terrains, coastal plain, alluvial fans, and drainage network (Fig. 3).

\section{The basement terrain}

It represents a wide watershed that is formed of igneous and metamorphic rocks and dissected by an intensive drainage network. It has elevation that reaches up to $2422 \mathrm{~m}$ above sea level (a.s.l) and decreases toward the southeast direction (to the Gulf of Aqaba). The basement terrain is considered as a horst block where it bounds by two rift systems: Gulf of Aqaba and Gulf of Suez (grabens). This unit is the responsible for receiving the majority of rainfall and directs them to the drainage basins.

\section{The coastal plain}

This plain represents a narrow zone which is bound by the Gulf of Aqaba from the east and the basement terrain to the west. It covers about $319 \mathrm{~km}^{2}$, with elevation ranges between 10 and $233 \mathrm{~m}$ a.s.l. The coastal plain can be classified as an urban area where it is occupied by many touristic infrastructures (villages, resorts, hotels, airport, roads, governmental firms, etc.). It was structurally originated and appears as connected deltas (fans) of the main channels. The plain is composed of consolidated reefs, coral reefs, sand beach, isolated hills, and sabkha. This unit can be considered as water collector due to its low elevation where all channel networks are draining to its surface.

\section{The alluvial fans}

They are developed along the Gulf of Aqaba coast, and are composed of basement terrain weathering products with various sizes: sand, gravels, and clay. These fans were created due to alluviation activities during the wet periods where they occupied the downstream portions of the drainage networks. Some fans are very well developed with its typical triangle shape such as Wadi Kid fan (with area $20 \mathrm{~km}^{2}$ ). This landform has a special interest in the current research, where its deposits are friable and poorly sorted which provide opportunities for groundwater recharge through flash flood events.

\section{The drainage network}

In the present study, 16 basins are extracted with dense drainage network dissecting the basement terrain and debouch it to the coastal plain and the Gulf of Aqaba. It is believed that these drainage lines are structurally controlled (compare Figs. 7 and 10 in the next sections), due to its characterization by trellis and rectangular shapes. The basement terrains include numerous lines of weakness (faults and/or joints) which contribute effectively in the development of this dense network and facilitate the groundwater recharge.

\section{Rainfall analyses}

The rainfall analysis of the study area was carried out through the data obtained from Sharm El Sheikh meteorological station. This data reveals that the annual rainfall ranges between 20 and $50 \mathrm{~mm} /$ year. However, the average annual rainfall during the period from 1942 to 2002 reaches to $23.8 \mathrm{~mm}$. It is clear that the area is 


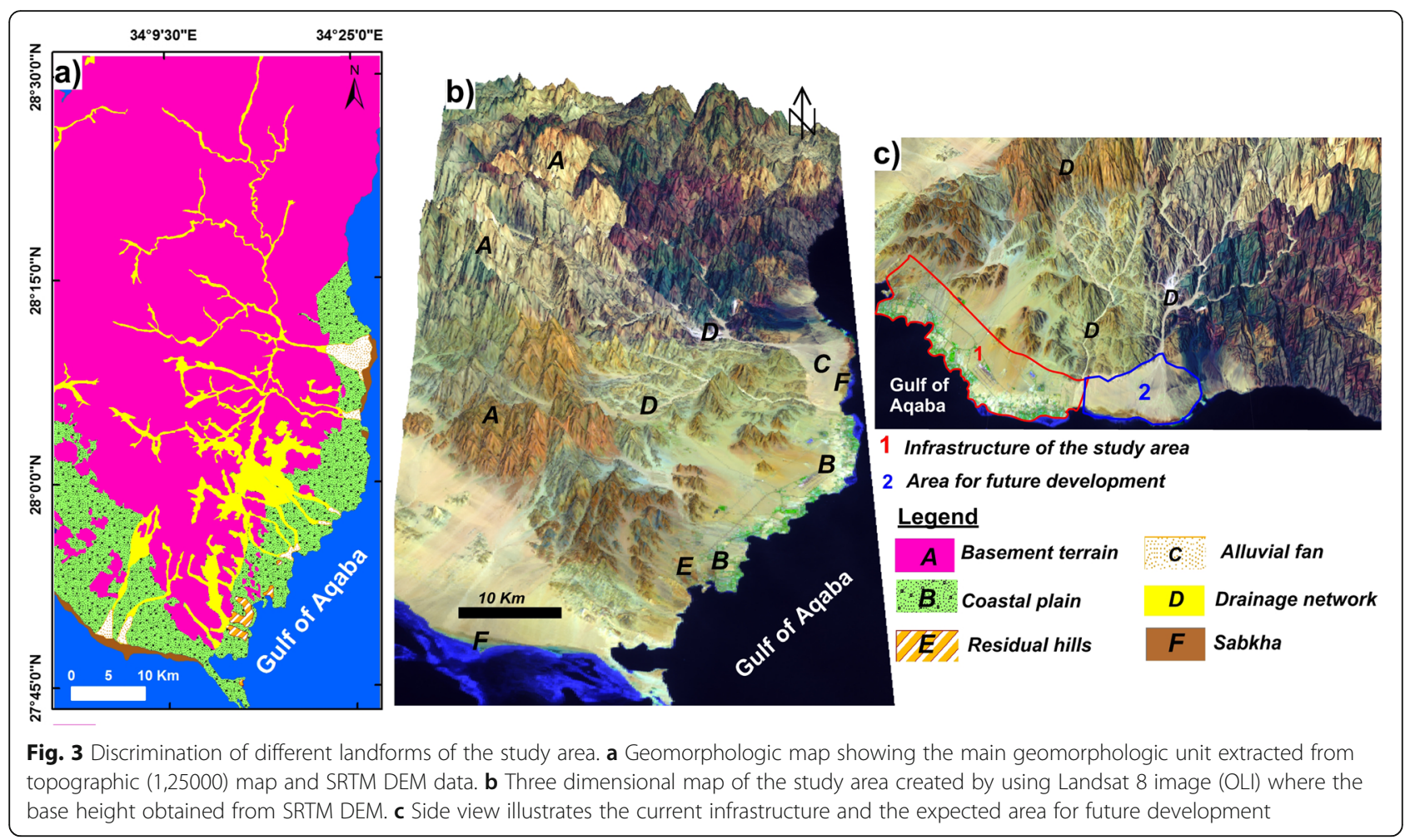

falling in a hyper arid zone with relative humidity less than $50 \%$. The rainfall is seasonal and usually falls in the winter season. Flash flood is usually resulted from a convectional storm or from an intensive rain. Any of these events or storms can produce a huge amount of surface runoff in short periods and affect all forms of life. Therefore, in the current study, the record of the highest single event occurred in Sharm El Sheikh, was used for estimation of surface runoff. The maximum total precipitation that was recorded in one day in the period from 1976 to 2010 reaches up to $59 \mathrm{~mm}$ (Sharm El Sheikh meteorological station) that occurred on 17 January 2010, (Fig. 4). This event has destructive effects on the city of Sharm El Sheikh and its vicinity. The contouring map of the maximum precipitation in one day for 7 meteorological stations (1976-2010) clarify that Sharm El Sheikh has the highest record in comparison with other stations (Fig. 4).

\section{Band ratios and principal component analyses}

For a better geological discrimination, the band ratios 4/ $3,6 / 2$, and $7 / 4$ were calculated from Landsat 8 images to identify the different rock and sediment units in correlation with their sources. This layer indicates that the source of Quaternary sediments is the basement rocks located to the south of the study area. The alluvial sediments that are recorded in El Qaa plain (to the west of the study area) is characterized by a deep thickness that exceeds $100 \mathrm{~m}$ (A in Fig. 5a) can be correlated with the alluvial fan deposits (C and D in Fig. 5a) in the study area. The Miocene exposures (B in Fig. 5a) can be discriminated through a band ratio layer than other alluvial sediment, where they have limited distribution. The comparisons between the obtained colors of alluvial Quaternary sediments and the main watershed of the basement terrain confirmed that these sediments were derived from basement rocks by the actions of water during the past wet period (Abotalib et al., 2019). The band ratio layers also elucidate precisely the different urban areas that include the infrastructures of Sharm El Sheikh where they are shown by the light green colors along the coast (Fig. 5b). The surface water flow direction that affected these areas has different trends and debouches directly to the touristic resorts. The results from the band ratio calculations are confirmed by using the principal component analyses (PCA), (Fig. 6a and b). The dark blue color distinguishes the alluvial fan deposits along the main channels that dissect the basement terrain and also along the Gulf of Aqaba coast. The PCA helps in drawing the real drainage network paths (light blue color) that are thought to be controlled by structural setting (faults and joints, Fig. 7).

\section{Structural lineaments analyses}

The structural lineaments layer was prepared, aiming to identify the faults and/or joints that affect the different rock exposures and can play an important role in the recharging processes. Structurally, the area of study falls 


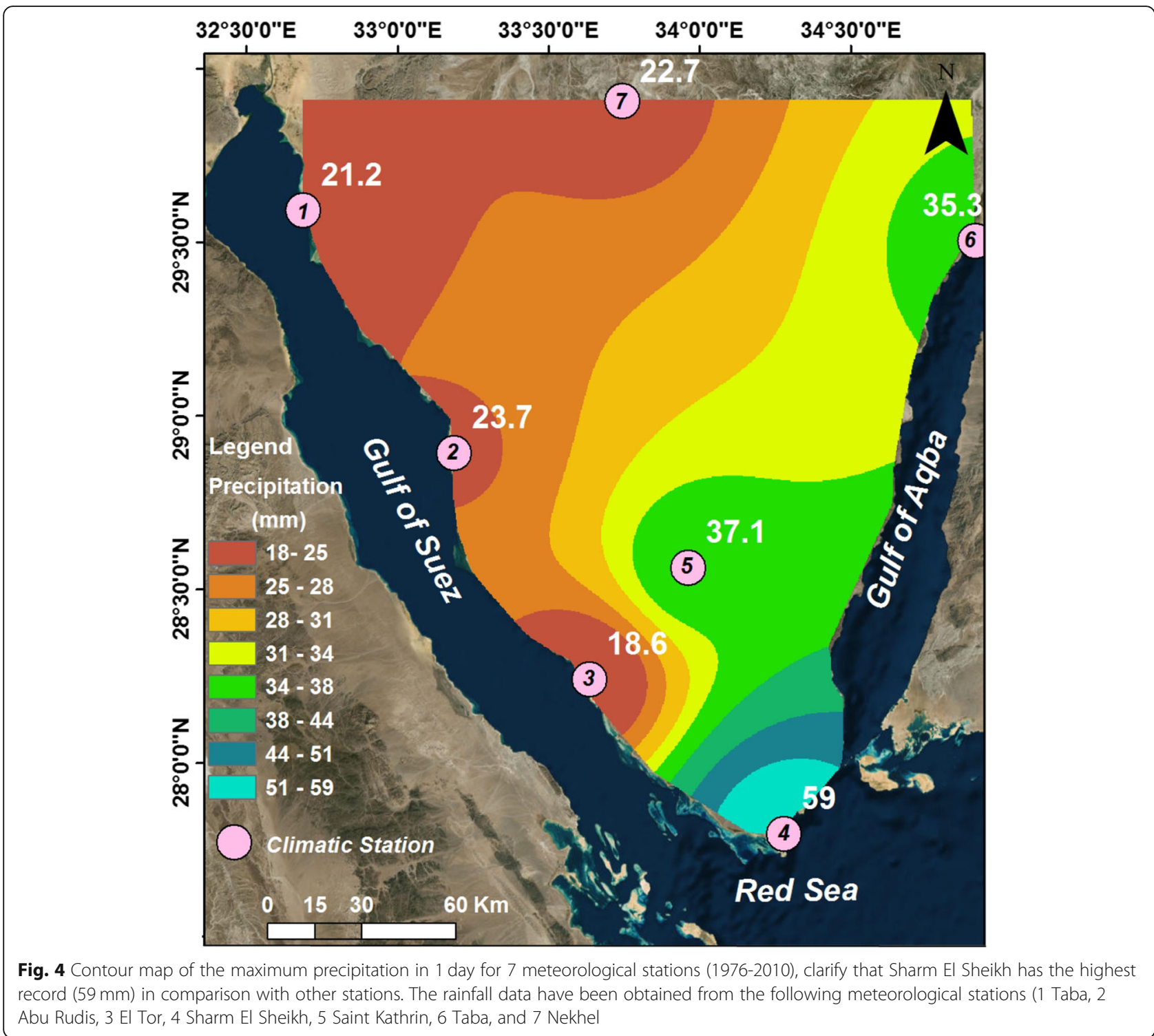

within a transition zone between two tectonic regimes: the Dead Sea to the north and the extension of the Red Sea to the south (Arnous and Green 2011). Given, the uplift of the basement rocks and the rifting system of the Gulf of Aqaba, the area is controlled by many faults and fractures. Based on the Landsat image 8 , the analysis of the DEM derivatives including shaded relief map, the structural lineaments were extracted and identified. The main trends of these lineaments are NE-SW, NW-SE, and N-S with obviously effect on the form and size of the sedimentary exposures (Fig. 7). The coastal plain and what it contains of alluvial fans were not affected by any surface structural lineaments.

\section{Geophysical and borehole data}

The aeromagnetic data (reduce to pole "RTP" map) of south Sinai indicates that the study area can be classified into one basin which has RTP values ranging between 600 to -450 nano Tesla (nT). The basin is divided by intermittent uplifts, which range in RTP values from 150 to $500 \mathrm{nT}$ (Fig. 8a). Additionally, the Euler deconvolution technique provides information about the position of the subsurface intruded magnetic bodies (basement) that show depths range from $100 \mathrm{~m}$ to about $10 \mathrm{~km}$ in Sinai. However, the study area has depths range from 100 to $1000 \mathrm{~m}$ along the coastal plain (Fig. 8b). Furthermore, based on the Euler solution method, a cluster has been obtained to indicate definite structural orientations (i.e., NE-SW, NW-SE, and N-S; Fig. 8c). These data are obtained and modified from Saleh and Saleh (2012). A detailed interpretation of the above mentioned data together with remote sensing datasets in a GIS environment resulted in a surface structural lineaments map as well as inferred deep-seated faults (Fig. 8c). A 


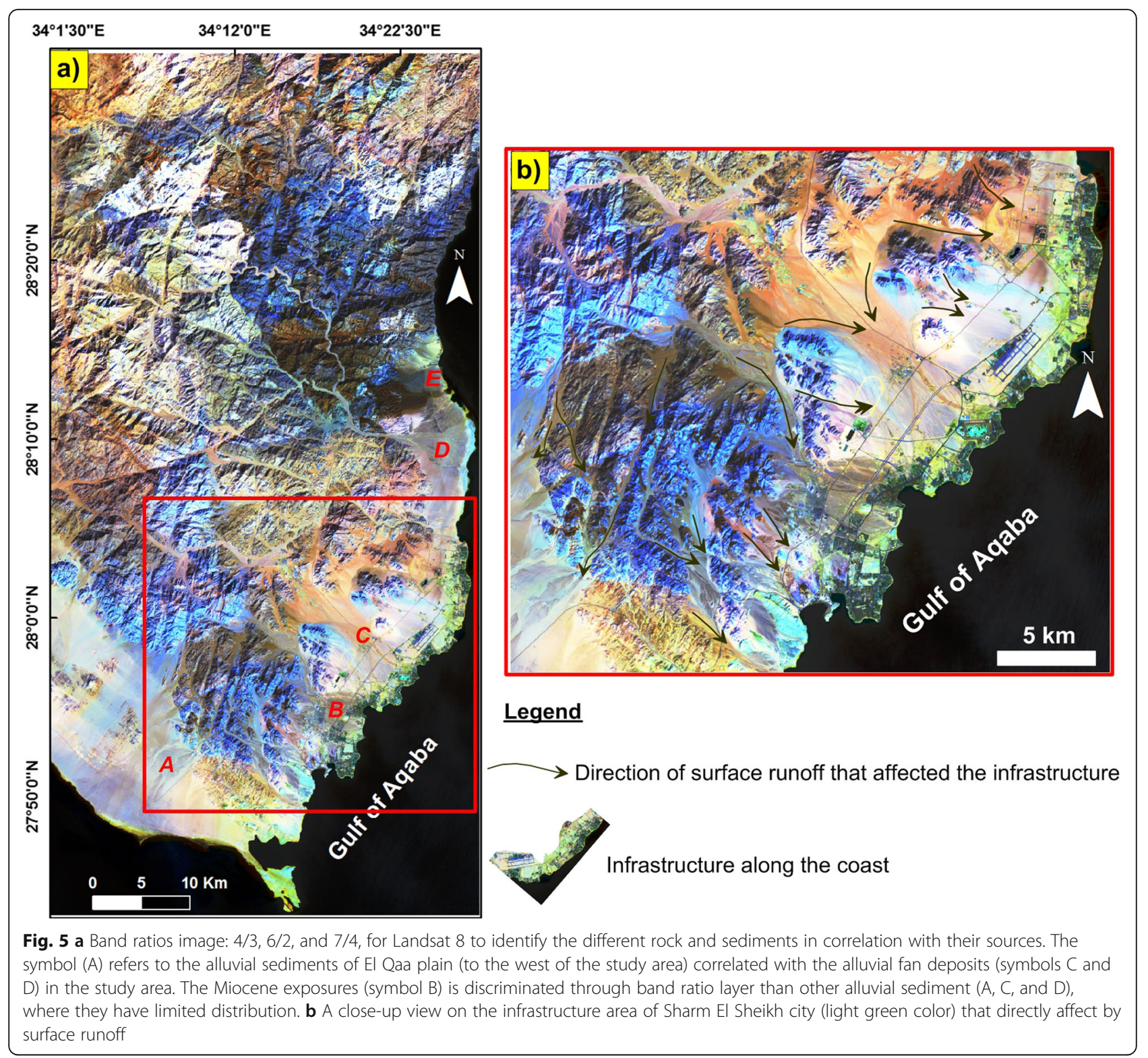

comparison of the surface lineaments and the deduced deep-seated faults indicate that both fault sets have the same orientation, which indicates that these surface lineaments are deeply extended and most likely a surface manifestation of the deep-seated structures (compare Figs. 7 and 8c). On the other hand, two vertical electrical sounding (VES) and four boreholes show the subsurface succession where they penetrate the Quaternary and Miocene sediments. The data obtained from the VES and boreholes as shown on the schematic cross sections A-A' and B-B' (Fig. 12) are compatible with the deduced fault map. This correlation illustrates the presences of subsurface sedimentary succession reaches to $200 \mathrm{~m}$ in the area between the uplifted basement rocks and the Gulf of Aqaba.

\section{Elevation and slope layers}

In hydrological studies, the topography is an important factor where slope has a fundamental role in regulating the surface runoff. Additionally, the gradient controls the relation between the surface runoff and infiltration, as the gradient increases the surface runoff increases and consequently decreasing the infiltration (Das 2018; Das and Pardeshi 2018; Das et al. 2018). The study area shows wide variations in elevation values where they are ranging between 3 and $2422 \mathrm{~m}$ (Fig. 9a). These variations are due to the structural setting which causes the basement uplift as a horst block, while the coastal plain represents the lowlands resulted from the Gulf of Aqaba rift. The lowland is considered as water collectors that receive all surface runoff from different directions where 


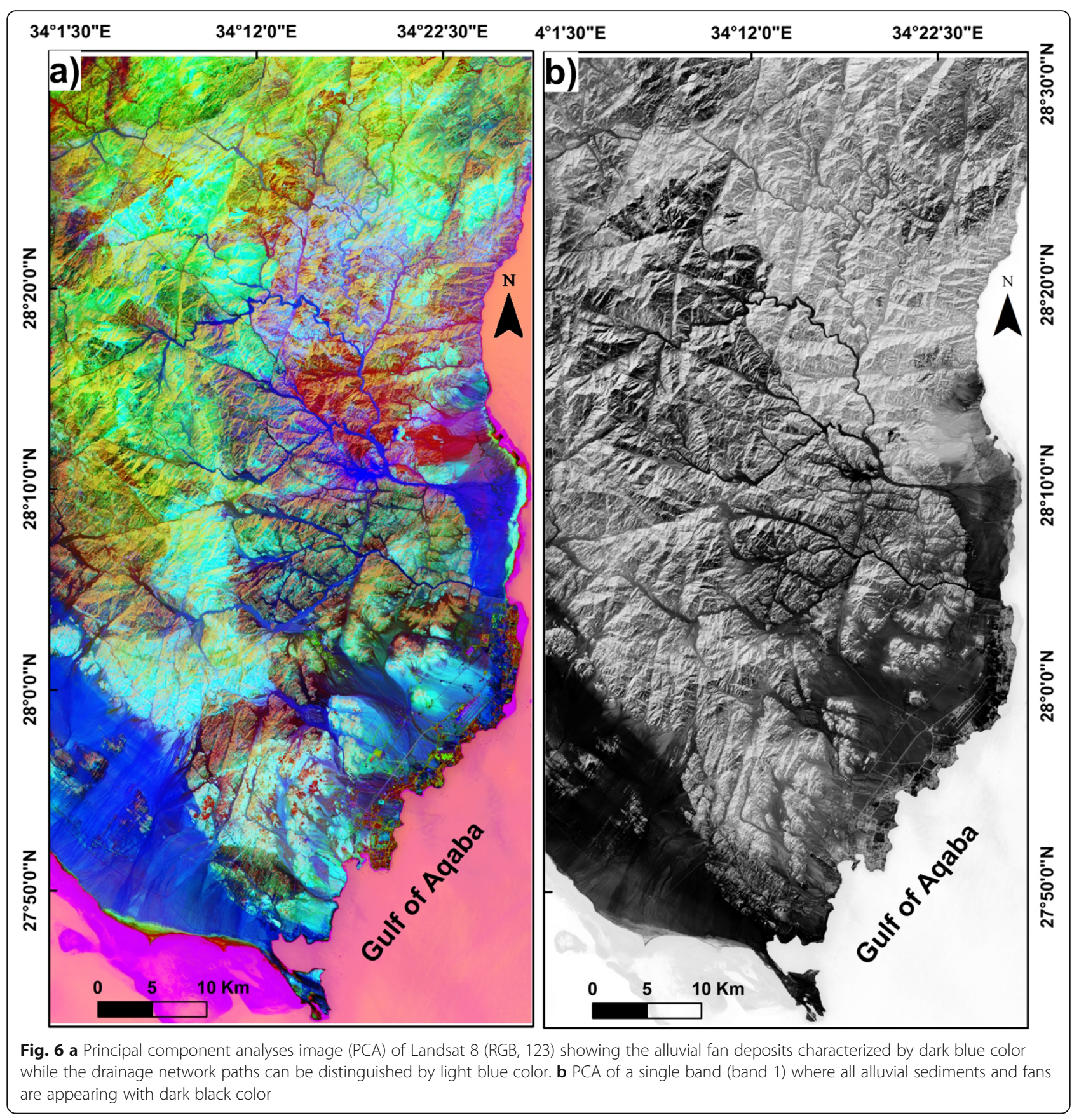

its elevation does not exceed $10 \mathrm{~m}$ a.s.l. On the other hand, the slope layer (Fig. 9b) clarifies the lowland that includes fans and coastal plain are characterized by a gentle slope $\left(0^{\circ}-8^{\circ}\right)$ while the basement terrains and the isolated hills have a steep slope $\left(>35^{\circ}\right)$. The areas with low slope values decelerate the surface runoff and increase the possibility of groundwater recharge.

Flow directions and alluvial deposits layers

The layer of flow direction (Fig. 10a) reveals that the surface runoff resulting from any rainfall events during rainy seasons has an east trend as the main direction $(18.68 \%)$. This main trend is followed by two trends: south $(16.73 \%)$ and southeast directions $(13.73 \%)$. This confirms that all surface runoff is draining to the city of Sharm El Sheikh and its vicinities. The flow direction layer is important for flood mitigation, particularly in case of the establishment controlling systems against these floods. On the other hand, the alluvial sediments (fans and wadi deposits) have an opposite effect on surface runoff and positive effect on the groundwater recharge. This is due to the composition and texture of 


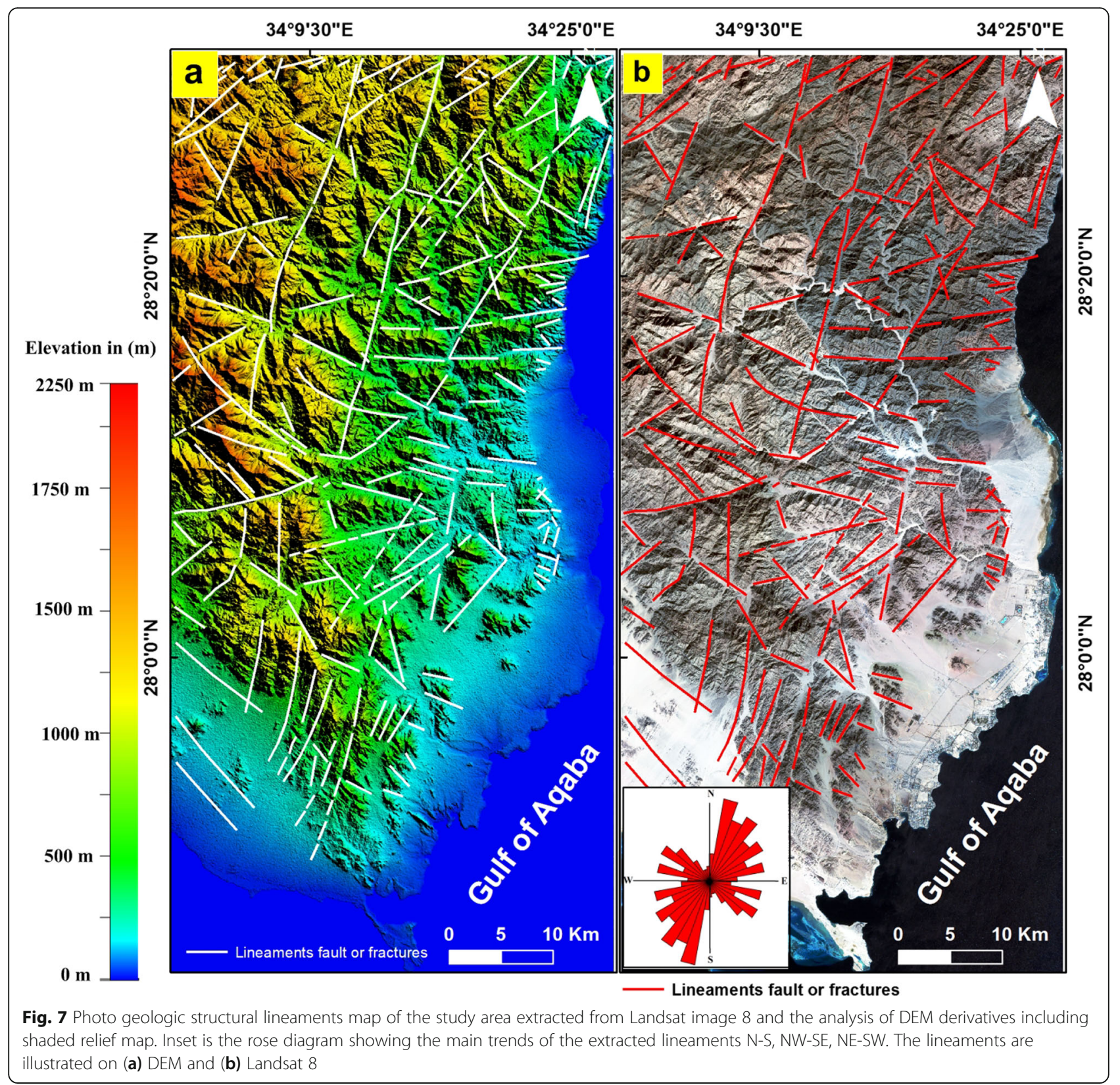

these sediments which are characterized by friable and losses grains mixed with gravels derived from basement terrains. The area of alluvial was elucidated and mapped through Landsat image analyses (Landsat 8) where it ranges between 3 and $73 \mathrm{~km}^{2}$ (Fig. 10b).

\section{Morphometric analyses}

The area of study consists mainly of 16 drainage basins (Fig. 11a); most of these basins flow to the east and south directions to the Gulf of Aqaba coast where it is occupied by touristic village, urban areas, and industrial sites. The area of these basins ranges between 7.5 (basin 16) to $1055.7 \mathrm{~km}^{2}$ (basin 4). Twenty-one morphometric parameters (Table 1) have been computed to the 16 basins and outlined in Table 2. These parameters assist in estimating the relative flood hazard degree and the possibility of the basins for receiving groundwater recharge for the shallow aquifer.

\section{Stream orders $(\mathrm{Nu})$ and stream length $(\mathrm{Lu})$}

The stream order of the studied basins range between 3rd order in (basin 16) to 7th order in (basin 4). The stream network patterns of the drainage basins are mainly angular streams (rectangular type), with some subparallel to subdendritic drainages, reflecting the effect of structural control (fault and joints) on stream 


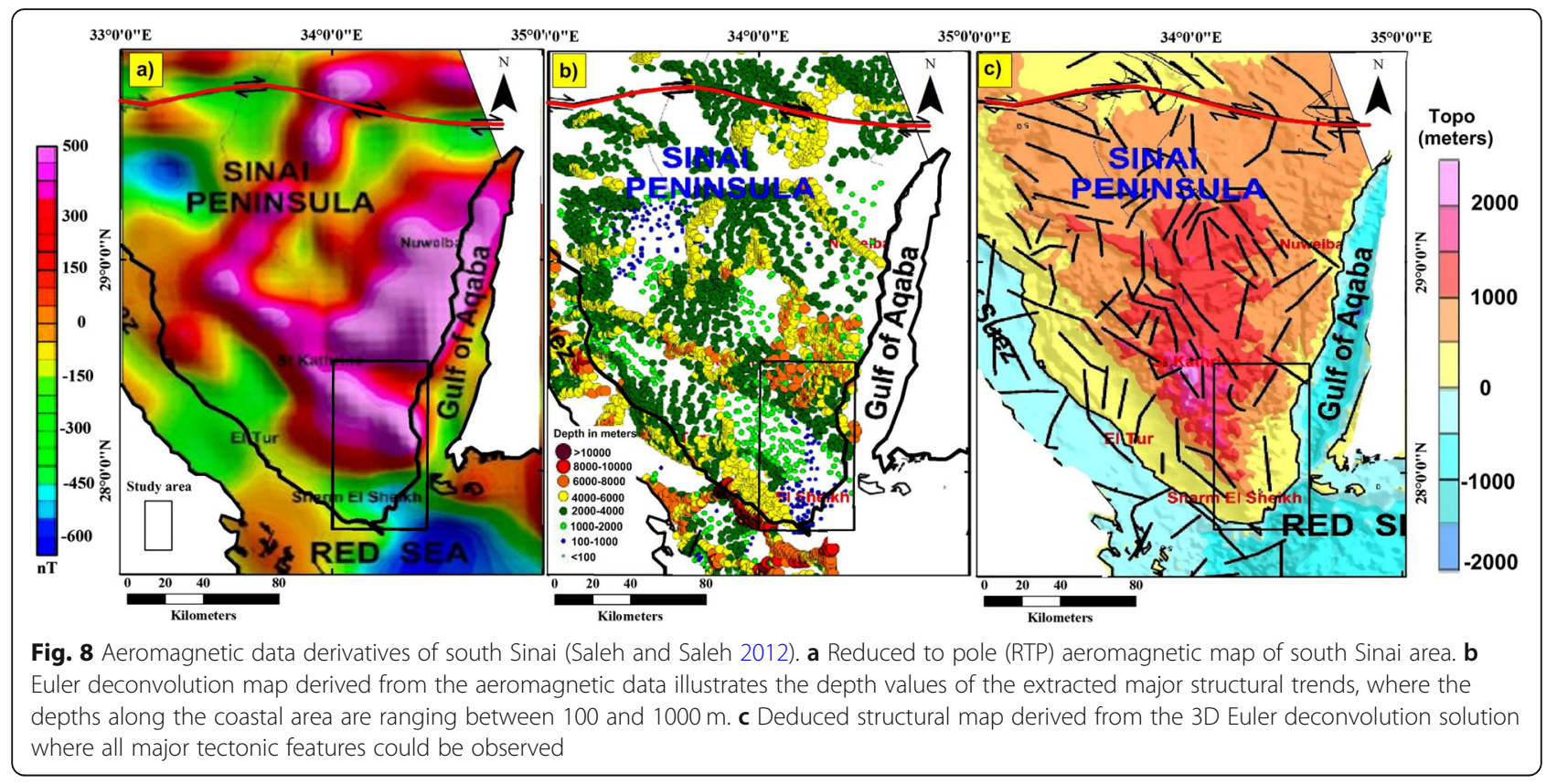

network (Fig. 11b). The total stream length in each basin ranges between $24 \mathrm{~km}$ in (basin 16) to $2322.7 \mathrm{~km}$ in (basin 4).

\section{Drainage density $(D)$ and stream frequency $(F)$}

Drainage density is considered an inverse function to the permeability, so it is an important factor in studying surface runoff. Low drainage density reflects slow hydrologic response to rainfall events and means poorly drained basin, while high drainage density means highly dissected basin with rapid hydrologic response to rainfall (Melton 1957; Gupta and Srivastava 2010). In the studied basins, the computed values of drainage density range between $2.2 \mathrm{~km}^{-1}$ (basin 4) to $3.3 \mathrm{~km}^{-1}$ (basin 16). These high values are developed in regions with specific characters (i.e., high mountainous relief, sparse vegetation, and low permeability). In other respect, the values of drainage frequency fall between $3 \mathrm{~km}^{-2}$ (basin 7 and 13) and $4.4 \mathrm{~km}^{-2}$ (basin 10). These high values of stream frequency reflect high runoff values providing opportunity of high flood hazard. This is the case in that study where basin 10 has a high flood hazard degree (Table 3).

\section{Shape index (Ish), texture ratio (Rt), and length of overland flow (Lo)}

The relation between the length and area of a basin is defined by the shape index of basin. The values of the shape index range between 0.1 and 0.4 reflecting an elongated shape for all the studied basins. The elongated shape of the studied basins provides a good chance for groundwater recharge from the surface runoff. Drainage texture reflects a number of natural factors (i.e., lithology, soil type, climate, rainfall, infiltration capacity, and relief aspect) of the terrain. Based on the classification of Smith (1958a, b), the textures of the studied basins are categorized as follows: very coarse (basins 2, 7 , 11,13 , and 14), coarse (basins 8, 9, 12, 15, and 16), moderate (basins 1, 2, 6, and 10), fine (basin 5), and finally very fine texture (basin 3 and 4). The length of overland flow is defined by the length of water flow path over the ground prior to its accumulation into a stream course. The values of Lo range between 0.15 (basin 16) and 0.21 (basins 11 and 12). These values indicate that the surface water is directed faster in basin 16 than basins 11 and 12.

\section{Ruggedness number $(R n)$, relief $(R)$, and relief ratio (Rr)}

Ruggedness number is expressed by the product of density (D) and relief (R). The high values of ruggedness number (4.4, 3.6, and 2.6) in basins 3, 4, and 5, respectively reflect very high relief, fine to very fine textured drainage basins. By comparing the high values of $\mathrm{Rn}$ with basin magnitude (flood potential), we found that the basins 3, 4, and 5 of high Rn values have high and very high hazard degree (Tables 2 and 3). Relief (R) is defined by the difference in elevation between the head and the mouth of the basin, while relief ratio $(\mathrm{Rr})$ is the ratio between the relief and the maximum basin length, which is measured parallel to the main stream. The values of $R r$ range between 0.021 and 0.059 in basins 14 and 8 , respectively. The high values of $\mathrm{Rr}$ in basins 3, 5, 8,10 , and 12 show high flood hazard degree, while the low values in basins 1 and 2 show low hazard degree (Tables 2 and 3). 


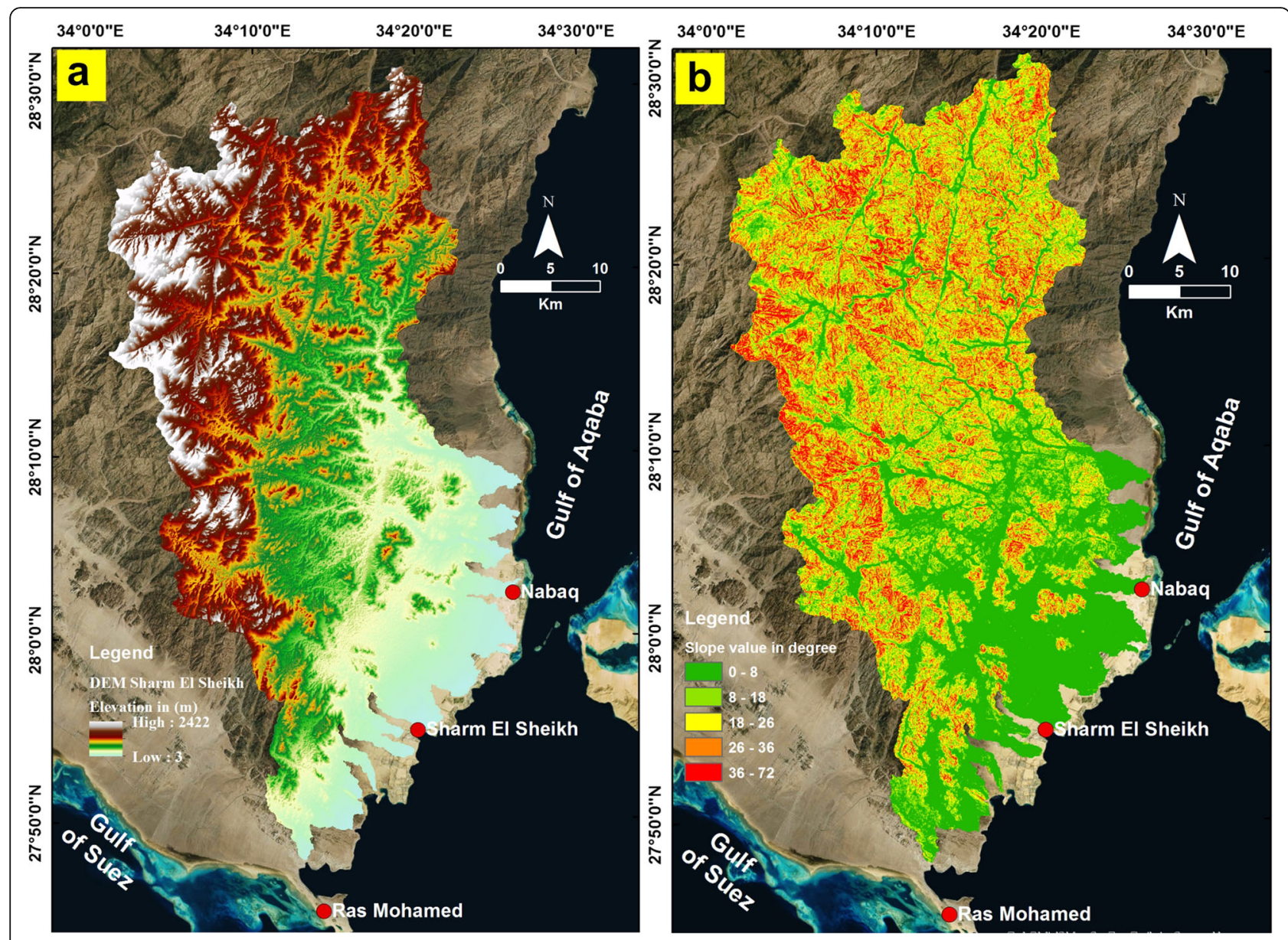

Fig. 9 a Elevation layer showing shows a wide variations in the values ranging due to the structural setting which cause the basement uplift as a horst block. $\mathbf{b}$ Slope layer clarifies the lowland that includes fans and coastal plain are characterized by gentle slope $\left(0^{\circ}-8^{\circ}\right)$ while the basement terrains and the isolated hills have steep slope $\left(>35^{\circ}\right)$

\section{Area of alluvial deposits (Av), sinuosity index (Si), and weighted mean bifurcation ratio (WMBR)}

The area of alluvial deposits is inversely proportional to the flood hazard degree and directly proportional with the groundwater recharge. So, it is an important factor in assessing the potentiality of groundwater recharge and flood hazard degree. The calculated values of the Av in the studied basins show that basins 3, 4, 5, 10, and 12 have low Av values with high to very high flood hazard degree, while basins 1, 2, 6, and 11 have high Av values and low flood hazard index means that these locations are favorable for groundwater recharging (Table 2 and $3)$. The sinuosity index $(\mathrm{Si})$ is an important parameter which has an inverse relation with flood strength. It is defined as the ratio between the length of the main stream (VL) and the basin length (BL), $\mathrm{Si}=\mathrm{VL} / \mathrm{BL}$ (Table 1). The high sinuosity values mean retardation of the surface runoff and giving more chance for the surface water to infiltrate and recharge shallow aquifer in addition to the reduction of flood hazard. Meanwhile, the low sinuosity values mean high flood strength with high hazard degree. In general, all obtained values more than the unity. The values of weighted mean bifurcation ratio (WMBR) are ranging from 4.1 to 6.9. These high values reflect the impact of structural control on the development of the drainage network.

\section{Flood hazard index}

This index was produced to express about the degree of hazard for each one of the morphometric parameters and to compare between the different basins. Seven parameters are affected directly proportional on the flash flood (A, SI, D, F, Ish, Rn, and Rt), and five parameters have inversely affected the flash flood (Av, WMRB, SLD, $\mathrm{Lo}$, and $\mathrm{Si}$ ). The values of these parameters with their proposed weight and FHI for each parameter are tabulated in Table 3. The weight of each parameter is proposed according to the careful understanding of the study area. The area included 16 basins; ten of them were selected for estimation of FHI where they have the 


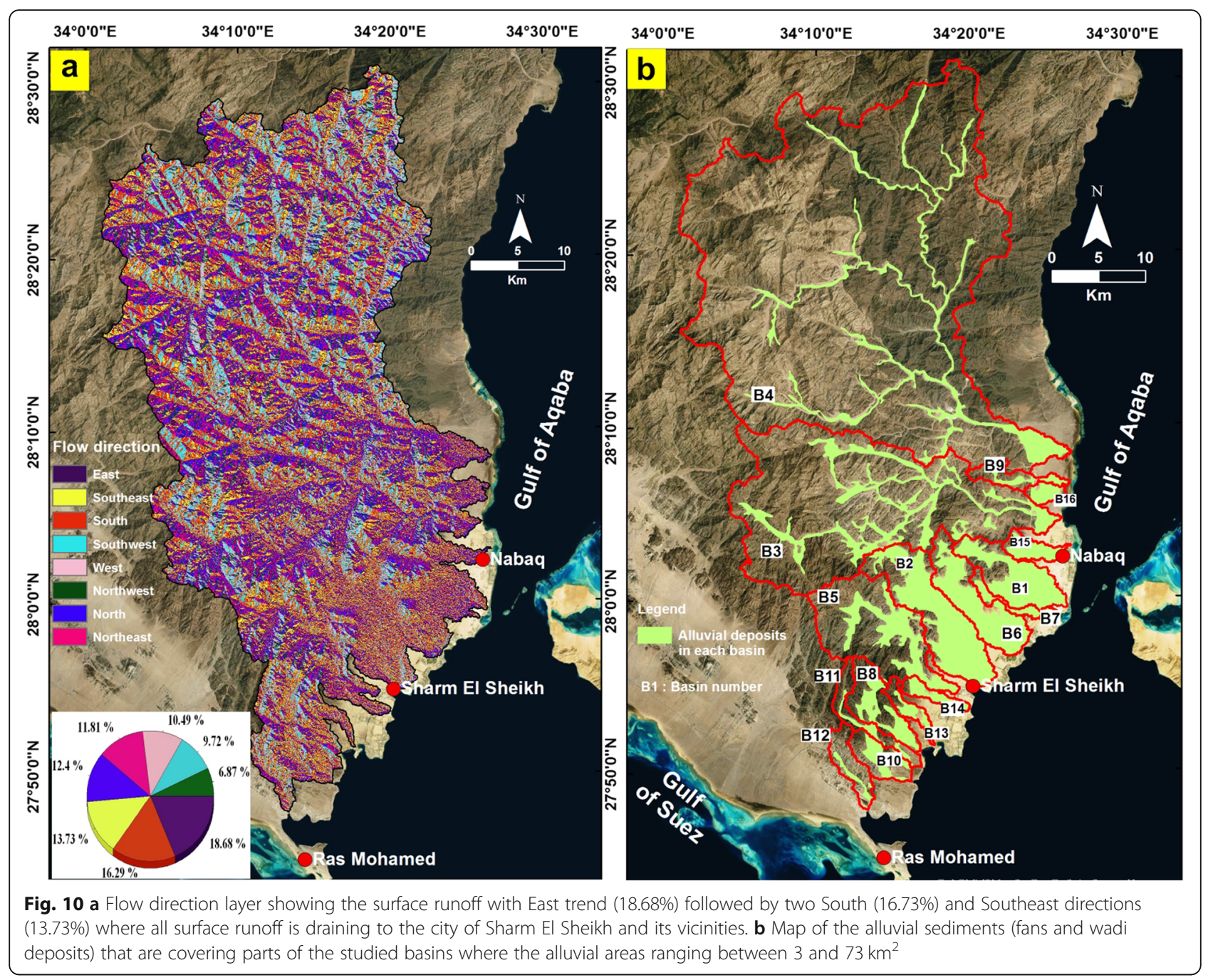

highest area values (basins nos. 1, 2, 3, 4, 5, 6, 8, 10, 11, and 12). The obtained values of FHI range between 55.2 (low) and 73 (very high). The studied basins are classified according to the FHI values to 4 classes, where basins nos. 1, 2, 6, and 11 are classified as low hazard degree, basin no. 8 as moderate, basins nos. 3, 5, 10, and 12 as high, and finally basin no. 4 as very high hazard degree (Table 3).

\section{Estimation of surface runoff}

The estimation of surface runoff (Q) was achieved through the curve number method. It was calculated for the basins, which have the largest areas (Table 4). According to the curve number method, the hydrologic soil characteristics are the main factor affecting the surface runoff value. Therefore, it was estimated for the areas that are covered by alluvial deposits where the other areas are occupied by basement rocks. The precipitation falls over basement terrains and is mainly spread and distributed due to the high fractures density of basement rocks. The curve number 68 is used for sandy soil in arid lands that contains desert shrubs (30\% ground cover, litter, grass, and brush). The surface runoff that resulted from a single event in 1 day $(59 \mathrm{~mm})$ is reached to 7.96 $\mathrm{mm}$. However, total runoff volume resulted from this event $(\mathrm{Qv})$ of an area "A" is ranging between $24 \times 10^{3}$ $\mathrm{m}^{3}$ (basin no. 12) and $585 \times 10^{3} \mathrm{~m}^{3}$ (basin no. 4). The evaluation of result outputs reveals that basins can receive surface runoff about $13.5 \%$ of the total single rainfall event of $59 \mathrm{~mm}$. The rest of rainfall is lost through infiltration and can recharge the groundwater. However, during the modeling of a single event that causes flood, the evapotranspiration is ignored (Ramirez 2000) due to its low magnitude during the event.

\section{Groundwater occurrences}

Hydrogeologically, the Miocene aquifer is considered as the main water bearing formation in the study area. Additionally, two formations are bearing groundwater including the Quaternary alluvial sediments and the fractured basement 


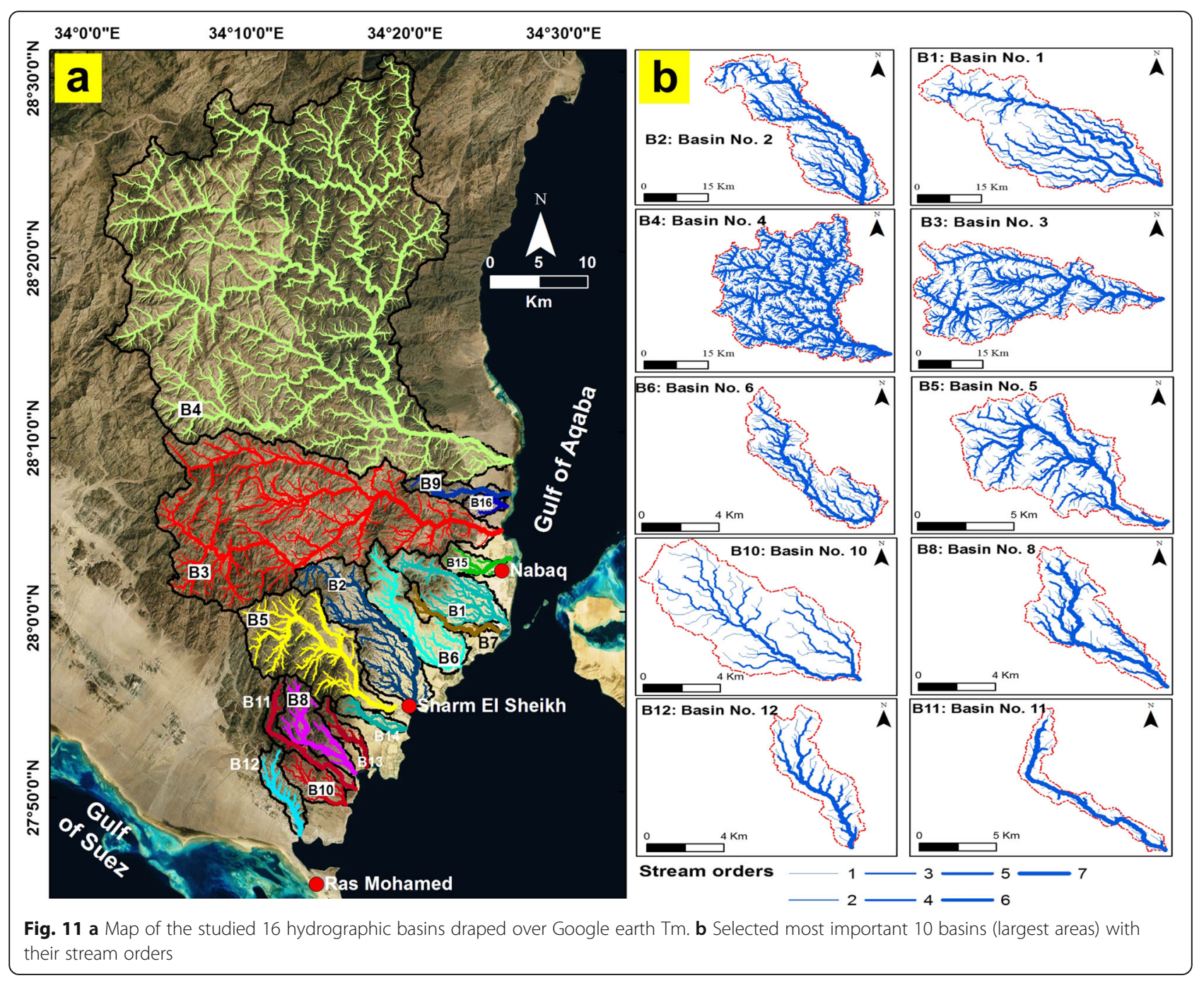

(Aglan 2015; Mohamed et al., 2015; Isawi et al. 2016). The Miocene aquifer is composed of limestone, dolomitic limestone, and coarse grained sandstone with shale intercalations. The subsurface data (wells and vertical electrical sounding "VES") of the studied area were obtained through the works of (Abdallah and El Hefnawy 2002 and Isawi et al. 2016). Two schematic cross sections are drawn: A-A' with main directions from NW to SE and B-B' from SW to $\mathrm{NE}$ direction (Fig. 12). The first one (A-A') indicates that the thickness of the Miocene aquifer exceeds $200 \mathrm{~m}$ and can be subdivided into three layers: coarse grained sandstone (top), fractured dolomitic limestone and limestone, and grained sandstone (base). Four faults are recognized in the area between the basement terrains to the Gulf of Aqaba. These faults can provide the opportunities for groundwater recharging. Isawi et al. (2016) stated that the total dissolved salt (TDS) values are between 13,551 and 75, $487 \mathrm{mg} / \mathrm{l}$ (average of $56,443 \mathrm{mg} / \mathrm{l}$ ), where the data of stable isotopes reflect that the water has a meteoric origin. The second cross section (B-B', Fig. 12) reveals that the area is dissected by a set of faults along the NE-SW direction. The Quaternary sediments are being recharged from the surrounding watersheds (basement terrains and isolated hills). Therefore, the Quaternary aquifer should be explored in other areas where it is thought to show a considerable thickness of more than $75 \mathrm{~m}$ thickness that reaches to +75 between VES 2 and basement; this is compatible with the approach of the current study that assumes the potentialities of Quaternary sediments to bear water and the Quaternary is only penetrated in the fan of Wadi Kid (basin no. 4) by one drilled well with depth to water of $43.9 \mathrm{~m}$ from the ground surface (TDS $=666 \mathrm{mg} / \mathrm{l}$ ). The seasonal rainfall and flash floods can be considered as the main sources for recharging both of Quaternary and Miocene aquifer. The groundwater of the Miocene aquifer as previously indicated shows a very high TDS values due to the sea water intrusion where this aquifer is penetrated in the coastal plain area which is closed to Gulf of Aqaba. Its water is used through the desalination plants to provide water for the touristic resorts. Although the Quaternary 


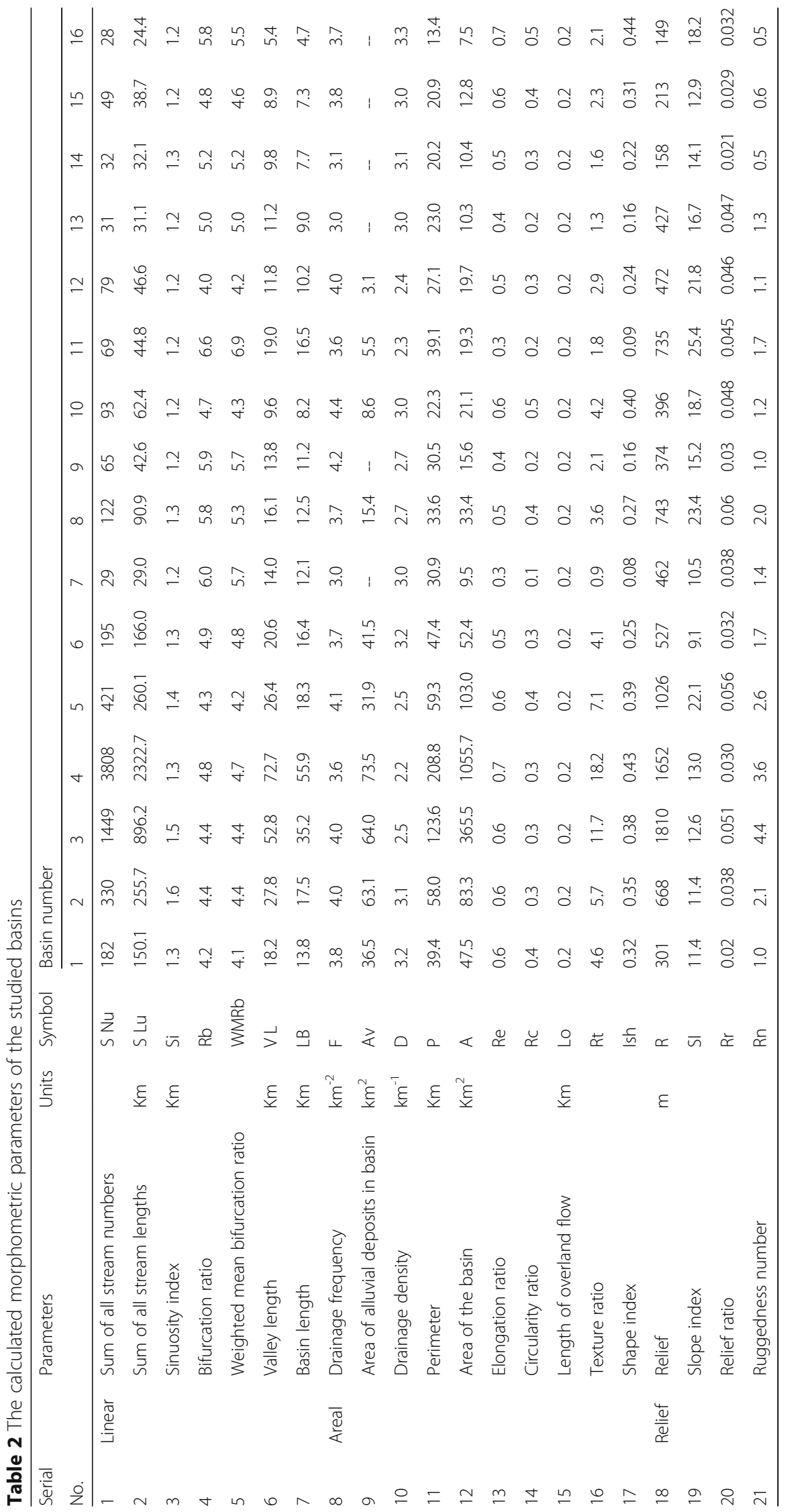


Table 3 Calculations of floods hazard index (FHI) of each basin

\begin{tabular}{|c|c|c|c|c|c|c|c|c|c|c|c|c|c|c|}
\hline \multirow{2}{*}{$\begin{array}{l}\text { Relationship } \\
\text { with hazard } \\
\text { degree }\end{array}$} & \multirow{2}{*}{$\begin{array}{l}\text { Parameters } \\
\text { (P) }\end{array}$} & \multirow{2}{*}{$\begin{array}{l}\text { Maximum } \\
\text { measured } \\
\text { value } \\
\left(X_{\text {max }}\right)\end{array}$} & \multirow{2}{*}{$\begin{array}{l}\text { Minimum } \\
\text { measured } \\
\text { value } \\
\left(X_{\text {min }}\right)\end{array}$} & \multirow{2}{*}{$\begin{array}{l}\text { Proposed } \\
\text { parameter } \\
\text { weight } \\
\text { (W) }\end{array}$} & \multicolumn{10}{|c|}{ Flood hazard index (FHI) } \\
\hline & & & & & $\begin{array}{l}\text { Basin } \\
\text { no. } 1\end{array}$ & $\begin{array}{l}\text { Basin } \\
\text { no. } 2\end{array}$ & $\begin{array}{l}\text { Basin } \\
\text { no. } 3\end{array}$ & $\begin{array}{l}\text { Basin } \\
\text { no. } 4\end{array}$ & $\begin{array}{l}\text { Basin } \\
\text { no. } 5\end{array}$ & $\begin{array}{l}\text { Basin } \\
\text { no. } 6\end{array}$ & $\begin{array}{l}\text { Basin } \\
\text { no. } 8\end{array}$ & $\begin{array}{l}\text { Basin } \\
\text { no. } 10\end{array}$ & $\begin{array}{l}\text { Basin } \\
\text { no. } 11\end{array}$ & $\begin{array}{l}\text { Basin } \\
\text { no. } 12\end{array}$ \\
\hline \multirow[t]{7}{*}{ Proportional } & $A$ & 1056 & 19 & 15 & 0.67 & 1.18 & 5.19 & 15.00 & 1.46 & 0.74 & 0.47 & 0.30 & 0.27 & 0.28 \\
\hline & $\mathrm{SI}$ & 25.36 & 9.14 & 15 & 6.76 & 6.74 & 7.42 & 7.68 & 13.09 & 5.40 & 13.81 & 11.07 & 15.0 & 12.9 \\
\hline & $\mathrm{D}$ & 3.17 & 2.2 & 7.5 & 7.48 & 7.27 & 5.80 & 5.21 & 5.98 & 7.50 & 6.44 & 7.01 & 5.5 & 5.61 \\
\hline & $\mathrm{F}$ & 4.42 & 3.58 & 7.5 & 6.51 & 6.73 & 6.73 & 6.12 & 6.94 & 6.32 & 6.20 & 7.50 & 6.08 & 6.82 \\
\hline & Ish & 0.43 & 0.09 & 5 & 3.67 & 4.02 & 4.37 & 4.98 & 4.55 & 2.86 & 3.15 & 4.60 & 1.05 & 2.8 \\
\hline & $\mathrm{Rn}$ & 4.44 & 0.95 & 7.5 & 1.61 & 3.47 & 7.50 & 6.14 & 4.38 & 2.82 & 3.42 & 1.98 & 2.89 & 1.8 \\
\hline & Rt & 18.24 & 1.67 & 5 & 1.27 & 1.56 & 3.21 & 5.00 & 1.95 & 1.13 & 0.99 & 1.15 & 0.48 & 0.8 \\
\hline \multirow[t]{5}{*}{ Inverse } & $A v$ & 73.46 & 3.06 & 5 & 0.42 & 0.24 & 0.24 & 0.21 & 0.48 & 0.37 & 1.00 & 1.78 & 2.8 & 5 \\
\hline & WMRB & 6.87 & 4.06 & 15 & 15.00 & 13.81 & 14.00 & 12.98 & 14.36 & 12.82 & 11.54 & 14.00 & 8.87 & 14.52 \\
\hline & SLD & 0.3835 & 0.001 & 5 & 0.10 & 0.03 & 0.01 & 0.02 & 0.01 & 0.10 & 0.02 & 5.00 & 0.01 & 5 \\
\hline & Lo & 0.227 & 0.158 & 7.5 & 7.50 & 7.28 & 5.81 & 5.21 & 5.99 & 7.50 & 6.45 & 7.02 & 5.51 & 5.62 \\
\hline & $\mathrm{Si}$ & 1.59 & 1.15 & 5 & 4.36 & 3.62 & 3.83 & 4.43 & 3.98 & 4.59 & 4.47 & 4.91 & 5 & 4.96 \\
\hline \multicolumn{4}{|l|}{ Total } & 100 & 55.3 & 55.9 & 64.1 & 73.0 & 63.2 & 52.2 & 58.0 & 66.3 & 53.5 & 66.2 \\
\hline \multicolumn{4}{|c|}{ Hazard degree } & & Low & Low & High & $\begin{array}{l}\text { Very } \\
\text { high }\end{array}$ & High & Low & Moderate & High & Low & High \\
\hline
\end{tabular}

aquifer has high recharge opportunity from precipitation and surface runoff, it is not explored yet in the study area.

\section{Discussion}

\section{Surface-groundwater interaction}

Although the study area is recognized as a hyper arid area, it receives some irregular flash floods. These arid regions were also subjected to past wet climate in the pluvial times that contributed in the paleo-recharge of groundwater aquifers (Yousif et al. 2018). The obtained results reveal that Sharm El Sheikh area received $59 \mathrm{ml}$ in one event occurred in January 2010. About $13.5 \%$ of the total precipitation amounts run as surface runoff where the remaining is thought to recharge the groundwater and saturate the soils before runoff. This result was confirmed through the stable isotope data (Isawi et al. 2016) where all groundwater samples of the Miocene aquifer are relatively falling close to the Mediterranean Meteoric Water Line (MMWL) indicating that they are of meteoric origin. They confirmed these results through the weighted average isotopic values of precipitation (- 4.99 and $-21.37 \%$ for $\delta^{18} \mathrm{O}$ and $\delta^{2} \mathrm{H}$,

Table 4 Estimation of surface runoff affecting the areas occupied by alluvial sediments

\begin{tabular}{|c|c|c|c|c|c|c|c|c|c|}
\hline \multirow{3}{*}{$\begin{array}{l}\text { Basin } \\
\text { number }\end{array}$} & \multicolumn{5}{|l|}{ Inputs } & \multicolumn{2}{|c|}{ Outputs } & \multicolumn{2}{|c|}{ Evaluation of outputs } \\
\hline & $\begin{array}{l}\text { Alluvial } \\
\text { area }(A)\end{array}$ & $\begin{array}{l}\text { Curve } \\
\text { number } \\
(\mathrm{CN})\end{array}$ & $\begin{array}{l}\text { Maximum daily } \\
\text { single event } \\
\text { precipitation }(P)\end{array}$ & $\begin{array}{l}\text { Potential } \\
\text { maximum } \\
\text { retention (S) }\end{array}$ & $\begin{array}{l}\text { Initial } \\
\text { abstraction } \\
\text { (la) }\end{array}$ & $\begin{array}{l}\text { Actual } \\
\text { runoff } \\
(\mathrm{Q})\end{array}$ & $\begin{array}{l}\text { Total runoff } \\
\text { volume for an } \\
\text { area "A" }(\mathrm{Qv})\end{array}$ & $\begin{array}{l}\text { Total volume of } \\
\text { precipitation for } \\
\text { area A }\end{array}$ & $\begin{array}{l}\text { Runoff }(Q) \text { to } \\
\text { precipitation }(P) \\
\text { Q/P }(\%)\end{array}$ \\
\hline & $\mathrm{km}^{2}$ & & Millimeter (mm) & $\begin{array}{l}\text { Millimeter } \\
(\mathrm{mm})\end{array}$ & $\begin{array}{l}\text { Millimeter } \\
(\mathrm{mm})\end{array}$ & $(\mathrm{mm})$ & $\begin{array}{l}\text { Cubic meter }\left(\mathrm{m}^{3}\right) \\
\times 10^{3}\end{array}$ & $\begin{array}{l}\text { Cubic meter }\left(\mathrm{m}^{3}\right) \\
\times 10^{3}\end{array}$ & $(\%)$ \\
\hline 1 & 36.5 & 68 & 59 & 119.50 & 23.91 & 7.96 & 291 & 2153.5 & 13.5 \\
\hline 2 & 63.1 & 68 & 59 & 119.50 & 23.91 & 7.96 & 502 & 3722.9 & 13.5 \\
\hline 3 & 64.03 & 68 & 59 & 119.50 & 23.91 & 7.96 & 510 & 3777.77 & 13.5 \\
\hline 4 & 73.46 & 68 & 59 & 119.50 & 23.91 & 7.96 & 585 & 4334.14 & 13.5 \\
\hline 5 & 31.91 & 68 & 59 & 119.50 & 23.91 & 7.96 & 254 & 1882.69 & 13.5 \\
\hline 6 & 41.5 & 68 & 59 & 119.50 & 23.91 & 7.96 & 330 & 2448.5 & 13.5 \\
\hline 8 & 15.35 & 68 & 59 & 119.50 & 23.91 & 7.96 & 122 & 905.65 & 13.5 \\
\hline 10 & 8.58 & 68 & 59 & 119.50 & 23.91 & 7.96 & 68 & 506.22 & 13.5 \\
\hline 11 & 5.47 & 68 & 59 & 119.50 & 23.91 & 7.96 & 44 & 322.73 & 13.5 \\
\hline 12 & 3.06 & 68 & 59 & 119.50 & 23.91 & 7.96 & 24 & 180.54 & 13.5 \\
\hline
\end{tabular}




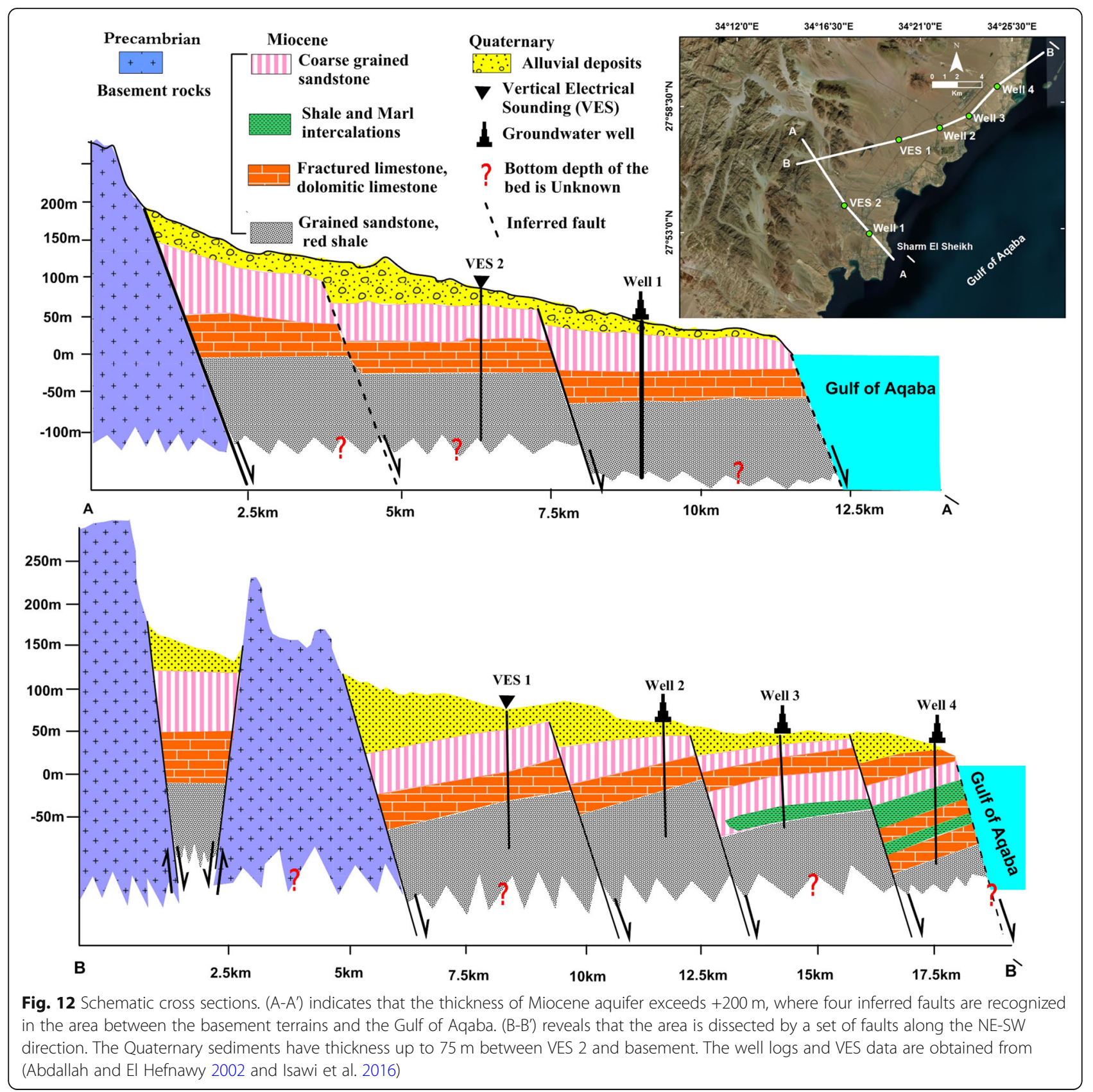

respectively, Eissa et al. 2013). Although some water amounts can be lost as evaporation and evapotranspiration, these amounts can be ignored due to its low magnitude during a single event (Ramirez 2000). However, the Gulf of Aqaba can be considered as one of the most vulnerable areas that can be subjected to the flash flood risks (Arnous et al. 2011). These flash floods are running and can cause damages until they drain to the Gulf (Sherief 2008). The watershed extension and altitude are among the principal elements that control the groundwater potentialities. These elements play a great role in controlling the amounts of the collected precipitation, the surface runoff, and the downward percolated water that recharge the shallow groundwater aquifers. The results of landforms demarcation (Fig. 3) identify the basement terrains as the main watershed while the coastal plain and the alluvial fans as the water collectors that characterized by low elevations and gentle slope (Fig. 9a and b). These lowlands can be considered as areas that are thought to have good groundwater potentialities where they receive runoff along the drainage network. However, the ability to bear water is depending on their thickness, therefore, the exploration should be carried out in the areas with considerable thickness. The band 
ratios and PCA analyses reveal that the Quaternary sediments in the study area is correlated with the same sediments in El Qaa plain that are characterized by a thick deposits exceed $100 \mathrm{~m}$. Consequently, the drawn cross section (Fig. 12, B-B') shows a thick deposits $(+75 \mathrm{~m})$ in some areas that is compatible with these results. The interpretation of structural lineaments and the two drawn cross sections (Figs. 7 and 11) confirmed the existence of a set of faults affected both Quaternary and Miocene deposits. These faults could act as a conduit between surface water and groundwater. Accordingly, the present study through light on the potentiality of Quaternary sediments as an aquifer that can provide a sustainable water resource for future development due to the opportunity of recharge through the occasional rainfall (Fig. 13). This viewpoint is illustrated through the designing of the conceptual model that clarifies the relationship between surface and groundwater and its recharge mechanism (Fig. 13a and b).

\section{Tectonic framework}

The main tectonic framework of the study area is resulted from the Gulf of Aqaba rift system. The Gulf of Aqaba was formed through two successive motions: the first is the pull-apart strike-slip motion that occurred during Late Miocene trending N-S (Garfunkel 1981). Several narrow grabens were resulted from this N-S fault. Then, the second motion had occurred with E-W extension during Pliocene-Quaternary time led to the Gulf of Aqaba opening (Mart 1982; Mart and Hall 1984). During the development of this complicated structural setting, the sedimentary succession of the Miocene was affected and formed a tilted blocks. These tilted blocks are similar to that resulted from the Gulf of Suez rift to the west of the study area (Ahmed et al. 2014). The drawing of the two schematic cross sections (Fig. 12) taking in consideration the mentioned two motions where A-A' (Fig. 12a) showing normal faults with horizontal beds, while B-B' (Fig. 12b) illustrates normal faults with inclined beds. This inclination is thought to be resulted from the pull-apart strike-slip and the E-W motions. The obtained results from surface lineaments analysis (Fig. 7) and the aeromagnetic data (Fig. 8c) are compatible with the directions of the motions causing the formation of the Gulf of Aqaba. Aforementioned discussion showing that the aquifers in the study area are structurally controlled where the delineated surface lineaments are deeply extended through the subsurface succession (refer to the "Geophysical and borehole data" section) which could provide chances for groundwater recharge.

\section{Environmental related impact of flash floods}

In arid and hyper arid environments such as Sharm El Sheikh area, the flash floods affecting directly on ecosystem balance. This can occur through soil erosions, transferring of rocks, and insects from watershed to water collector areas, and also damage of the natural parks located along the coast of Aqaba Gulf. Moreover, the environmental problems resulted from flash flood are extended to human life. For example, the flash flood affected Sinai in 2010 caused cutting roads, sweeping away homes, damaging power lines, and also it led to claim the life of 12 people in four different regions of Egypt (including the study area), (IFRC 2010). In addition, great numbers of houses in the four areas were hit by this flash flood. On the other hand, the monitored environmental problem during the current study clarifies that the Miocene aquifer is subjected to severe degradation. The average TDS of the Miocene groundwater reveals an increase through the last decades are as follows: $27,550 \mathrm{mg} / \mathrm{l}$ (1997); 33,000 mg/ 1 (2002); 34,000 mg/l (2007), (El-Refeai 1992; Awwad et al. 2008); and 56,443 $\mathrm{mg} / \mathrm{l}$ (measured in 2013, Isawi et al. 2016). This degradation could be attributed to sea water intrusion where wells were drilled along the coastal plain, and discharge of rejected brine water (waste of desalination plant) to the aquifer. The Miocene groundwater is used to provide water supply to the desalination plants in this area to serve the touristic resorts through many production wells. In the adjacent locations of these wells, the discharge wells were drilled that cause deterioration of the aquifer causing a serious environmental problem due to scarcity of fresh water. Therefore, the rainwater harvesting and flash floods mitigation system can provide alternative water resource and enhance the groundwater quality. Moreover, the report of (IPCC 2014) indicated that the water resources will have stresses from over demand and degradation in the future where adaptation plans should include decreasing non climatic strains on these resources. Based on the climatic analyses, the North African region shows raising in temperature associated with precipitation decreases (Yousif et al. 2016). The variation of atmospheric and oceanic processes, as well as human interference, influence the hydrological cycle at multi spatiotemporal scales (Salas et al. 2012). A continuous increase in temperature can lead to enhancing the frequency of flash floods. The sea level changes and global warming can lead to flooding hazard events that cause a serious effect on the coastal areas (Yuan et al. 2017). They clarified that global warming creates many drastic storms, such as typhoons, which consequently raise the level of flash flood hazard. Consequently, the proposed system introduced by the current study is vital for environmental protection of the study area under the climate changes.

\section{Flash flood mitigation}

Sharm El Sheikh City represents one of the most famous and attractive touristic areas in the world that are prone to seasonal flash floods. The area that is occupied by 


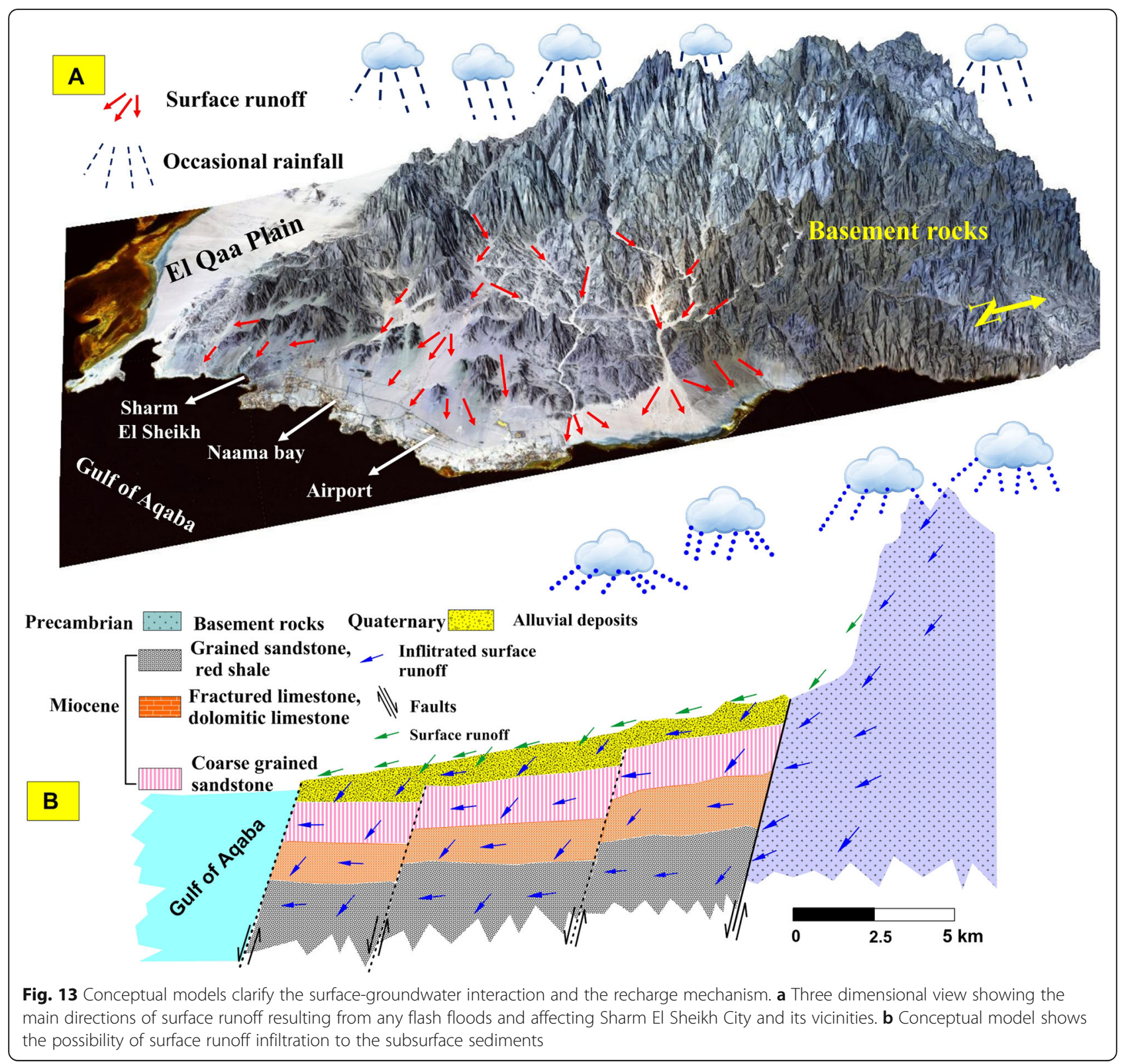

touristic resorts and villages reaches approximately 70 $\mathrm{km}^{2}$ while the main road in the study area has length about $106 \mathrm{~km}^{2}$. Additionally, the study area includes an international airport, Sharm El Sheik airport. These infrastructures were established along the flood course of about 16 drainage basins (Figs. 2 and 5); therefore, flash flood can cause significant destructions and losses of money and lives. In case of data scarcity, the flash flood assessment and classifications can be achieved according to the effective morphometric parameters of each basin (Yousif and Bubenzer 2015). The potential of flash flood hazard was estimated for the 10 largest basins debouching to Sharm El Sheikh area relatively to each other (Table 3). Furthermore, the assessment of single flash floods affecting the South Sinai reveals that the highest value was recorded from Sharm El Sheikh Station in 2010 reached to $59 \mathrm{ml}$ (Fig. 4). Most of the rains which fall over the basement terrains are distributed and spreading where these terrains are mainly fractured and dissected by faults and joints (Fig. 7). Accordingly, the estimation of surface runoff (Table 4) is focusing on the areas that covered by alluvial deposits. The investigated basins that mostly are covered by alluvial deposits have low FHI relative to other ones (Table 3). This is due to the high permeability of the loose sands and gravels which facilitate the recharge processes and decrease the surface runoff (as in case of basins nos. 1, 2, 6, and 11, Fig. 10b). Other basins show moderate, high, and very 
high hazard degree, and the flood is zapping directly to airport, Napaq national park, resorts, and also the proposed area for future development (Figs. 2 and 10a).

Aforementioned discussion reveals the dire needs of this touristic area for establishing a controlling system to mitigate the flash flood hazards. This system will serve to protect the current infrastructures and any touristic extension in the study area along the coast of Aqaba Gulf as well as maximizing opportunists to recharge the groundwater aquifers. This system should include the following items (Fig. 14):

a. Alternative dykes to decelerate the flood speed and act to divide its load where any flood can bring rocks and fragments from the watershed that increase its destructive effects. These dykes can be established from the country rocks along the main channels of each basin (Fig. 14b) b) Barriers in the form of embankment dams (zigzag path) should be settled for protection of the tourist resorts and airport that can be built along the main channel inside the basin. These embankment dams imped the surface runoff to increase the residence time and give chance for the Quaternary alluvial to be recharged (Fig. 14a).

c) The main asphalt road that links between Sharm El Sheikh and other cities should be protected through a group of culverts to permit water to path under the road without destroying its skeleton and without threatening cars, buses, and humans.

\section{Future groundwater explorations}

The coastal areas that belong to hyper arid regions are extremely vulnerable with regard to hydrological and environmental changes (Yousif et al. 2016). Furthermore, the data scarcity of such regions is a great challenge for groundwater investigations at practical scales (Yousif and Sracek 2016). The current water supply for Sharm

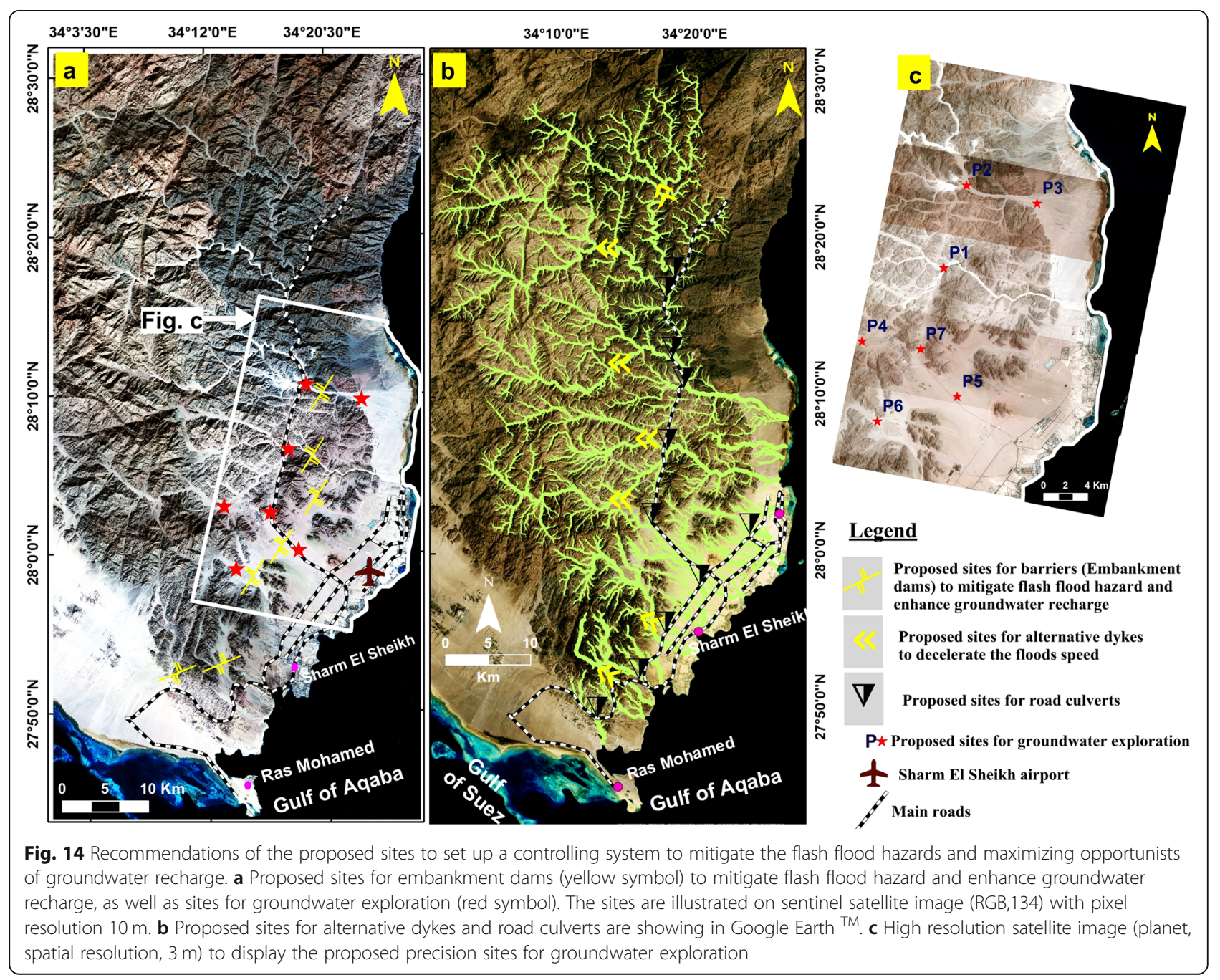


El Sheikh city is mainly dependent on desalination plants of Miocene aquifer as well as transferring the water from El Tor city that is far about $100 \mathrm{~km}$ from the city. As mentioned in the results section, the Miocene aquifer has a very saline water due to salt water intrusion (Isawi et al. 2016) while the Quaternary aquifer is not explored yet. During the last decades, as a result of increasing the number of touristic resorts and the population growth, the continuous groundwater extraction has increased; therefore, the Miocene aquifer has been deteriorated due to over pumping that exceeds natural recharge (Isawi et al. 2016). A conceptual model (Fig. 13a and b) reveals the possibility of recharge to this aquifer through rainfall and surface runoff. The potentiality of the aquifer depends on the thickness of its deposits which is decreasing toward the coast while the fan areas are expected to have a considerable thickness. Therefore, the proposed sites for groundwater exploration of the Quaternary aquifer (Fig. 14a and c) should be subjected to geophysical studies and drilling of test wells to evaluate its potentialities. These sites were identified based on the obtained GIS layers including water collector landform (Fig. 3), alluvial deposits (Fig. 2), low elevation (Fig. 8a), gentle slope (Fig. 8b), faults (Figs. 7 and 11), cross sections, and VES (Fig. 12), drainage lines (Fig. 11), area of alluvial (Fig. 9b), and flow direction that path through these sites (Fig. 9a). A high resolution satellite image (planet) with $3 \mathrm{~m}$ pixel size (Fig. 14c) is used for more clarifications of these sites. Consequently, the exploration of groundwater of the Quaternary aquifer can provide an ideal solution for water supply in the study area.

\section{Conclusion}

This research introduces a cost effective, multidisciplinary research approach to mitigate the flash flood hazards, and to maximize the possibilities of groundwater recharge for the different aquifers. The study displayed the environmental related problems resulted from flash flood and its impact on human life. For example, the flash flood affected Sinai in 2010 caused cutting roads, sweeping away homes, damaging power lines, and also it led to claim the life of 12 people in four different regions of Egypt. The present approach is based on remote sensing and GIS applications that help in producing multi thematic layers to evaluate flash flood hazards and to investigate the mechanism of groundwater recharge. The study clarifies that in case of data scarcity, the flash flood assessment and classifications can be achieved according to the effective morphometric parameters of each basin. Therefore, flood hazard index (FHI) is produced to estimate the degree of hazard for each morphometric parameter and to compare between different basins. In addition, the curve number method is used to estimate surface runoff where it was considered the best for arid environment due to that it based on many variables that control the runoff. On the other hand, the present study illustrates that the floods can provide chances for groundwater recharge; therefore, identifying the subsurface sedimentary succession is necessary. In this regard, the geophysical data included aeromagnetic, and the vertical electrical soundings provide adequate support for the study in the integration with remote sensing data. Also, the conceptual model and the schematic cross sections point up the recharging opportunities and its mechanism for the subsurface sediments. Consequently, a controlling system for flood mitigation and enhancing groundwater recharge as well as sites for groundwater exploration were proposed. The presented approach can be applied in any arid and hyper arid regions with the same conditions.

\section{Abbreviations}

FHI: Flash hazard index; DEM: Digital elevation model; VES: Vertical electrical sounding

\section{Acknowledgements \\ The authors are grateful for Desert Research Center that provides all facilities to carry out this research. We appreciate the efforts of Dr. Abotalib Z. Abotalib (Western Michigan University, USA) for his English reviewing of the manuscript; and for Professor Ahmed Saleh (National Research Institute of Astronomy and Geophysics "NRIAG") for his fruitful discussion about the aeromagnetic data.}

\section{Authors' contributions}

Mohamed, Yousif and Hussien, M. Hussien, performed the research, analyzed the data, and wrote the paper. Both authors have approved the final article.

\section{Funding}

This research did not receive any specific grant from funding agencies in the public, commercial, or not-for-profit sectors

\section{Availability of data and materials}

All data generated or analyzed during this study are included in this manuscript.

Ethics approval and consent to participate

Not applicable.

Consent for publication

Not applicable.

\section{Competing interests}

Both authors declare that they have no competing interests.

Received: 21 January 2020 Accepted: 23 March 2020

Published online: 10 April 2020

\footnotetext{
References

Abd Allah AA (1999) Geological and geophysical studies for groundwater investigation in Sharm El-Sheikh-Ras Mohamed area South Sinai, Egypt. Dissertation, Ph. D., Al Alzhar University Cairo Egypt.

Abdallah AA, El Hefnawy MA (2002) Groundwater investigation at Sharm ElSheikh area, South Sinai, Egypt. Annals Geological Survey Egypt, 417-427.

Abdeltawab S (2012) Rock fall failure model practical example of Umm Sid Plateau-Sharm El Sheikh area, Egypt. Int J Sci Eng Res 3(10):2229-5518

Abotalib AZ, Mohamed RS (2013) Surface evidences supporting a probable new concept for the river systems evolution in Egypt: a remote sensing overview. Environ Earth Sci 69(5):1621-1635
} 
Abotalib AZ, Sultan M, Elkadiri R (2016) Groundwater processes in Saharan Africa: implications for landscape evolution in arid environments. Earth Sci Rev 156: 108-136

Abotalib AZ, Sultan M, Jimenez G, Crossey L, Karlstrom K, Forman S, Polyak V (2019) Complexity of Saharan paleoclimate reconstruction and implications for modern human migration. Earth Planet Sci Lett 508:74-84

Abu-Alam TS, Stüwe K (2009) Exhumation during oblique transgression: an example from the Feiran-Solaf region, Egypt. J Metamorph Geol 27:439-459

Aggour TA (1999) Priorities of flood insurance, Gulf of Aqaba region, southeast Sinai, Egypt. Desert Institute of Egypt Bulletin 49:371-400

Aggour TA, Shabana AR, Shided AG, Yehia MM (2000) Hydrogeological conditions of the water bearing formations in Wadi Watir basin with emphasis on the deep ones. 2nd International Conference on Basic Science and Advanced Technology, Faculty of Science Assiut University, 1-13.

Aglan OSH (2015) Contribution of structural lineaments and geomorphologic characteristics to demarcate the recharging areas in Wadi Kid, southeast Sinai, Egypt. Journal of the sedimentological society of Egypt 22:185-201

Ahmed M, Sauck W, Sultan M, Yan E, Soliman F, Rashed M (2014) Geophysical constraints on the hydrogeologic and structural settings of the Gulf of Suez rift-related basins: case study from the El Qaa Plain, Sinai, Egypt. Surv Geophys 35(2):415-430

Allama AR, Saaf EJ, Dawoud MA (2002) Desalination of brackish groundwater in Egypt. Desalination journal 152:19-26

Ansari ZR, Rao LAK, Yusuf A (2012) GIS based morphometric analysis of Yamuna drainage network in parts of Fatehabad area of Agra district, Uttar Pradesh. J Geol Soc India 79:505-514

Arnous MO, Green DR (2011) GIS and remote sensing as tools for conducting geo-hazards risk assessment along Gulf of Aqaba coastal zone, Egypt. J Coast Conserv 15(4):457-475

Awwad RA, Olsthoorn TN, Zhou Y, Uhlenbrook S, Smidt E (2008) Optimum pumping-injection system for saline groundwater desalination in Sharm El Sheikh. Water Mill Working Paper No. 11, 1-21.

Bayoumi Al, Boctor JG (1970). Geological significance of gravity and magnetic anomalies in Rahmi area, Gulf of Suez district, U.A.R. 7th Arab Pet. Con., Secret. Gen. Leag. Arab State, Kuwait, 2 (36): B-2 (28).

Bentor YK (1985) The crustal evolution of the Arabo-Nubian Massif with special reference to the Sinai Peninsula. Precambrian Res 28:1-74

Chae HS, Kim SJ, Ryu JA (1997) A classification of multi-temporal Landsat TM data using principal component analysis and artificial neural network. In Geosciences and Remote Sensing. (1997). IGARSS'97. Remote Sensing-A Scientific Vision for Sustainable Development. IEEE International 1:517-520

Clarke J (1966) Morphometry from maps, essays in geomorphology. Elsevier Publication, New York

Das S (2018) Geographic information system and AHP based flood hazard zonation of Vaitarna basin, Maharashtra, India. Arab J Geosci 11(19):576 https://doi.org/10.1007/s12517-018-3933-4

Das S, Gupta A, Ghosh S (2017) Exploring groundwater potential zones using MIF techniques in semi-arid region: a case study of Hingoli district, Maharashtra. Spat Inf Res 25(6):749-756 https://doi.org/10.1007/s41324-017-0144-0

Das S, Pardeshi S.D. (2018). Comparative analysis of lineaments extracted from Cartosat, SRTM and Aster DEM: a study based on four watersheds in Konkan region, India. Spat. Inf. Res 26(1):47-57. https://doi.org/10.1007/s41324-0170155-x

Das S, Pardeshi SD, Kulkarni PP, Doke A (2018) Extraction of lineaments from different azimuth angles using geospatial techniques: a case study of Pravara basin, Maharashtra, India. Arab J. Geosci. 11(8)160. https://doi.org/10.1007/ s12517-018-3522-6

David CG (1984) Structural geology of the Quseir area, Red Sea Coast, Egypt. M.S. Thesis, University of Massachusetts.

Desconnets JC, Taupin JD, Lebel T, Leduc C (1997) Hydrology of the HAPEX-Sahel Central Super-Site: surface water drainage and aquifer recharge through the pool systems. J Hydrol 188-189:155-178

Drury SA (1987) Image interpretation in geology. Allen and Unwin, London. Egyptian Geological Survey and Mining Authority (EGSMA), (1994). Geological map of South Sinai scale 1:250,000.

EGSMA: Egyptian Geological Survey and Mining Authority (1994) Geological map of Sinai, Arab Republic of Egypt. Scale 1:250,000.

Eissa M, Thomas JM, Pohll GM, Hershey RL, Dahab K, Dawoud M, Gomaa M, E Shiekh A (2013) Groundwater resource sustainability in the Wadi Watir delta, Gulf of Aqaba. Hydrogeol J 21(8):1833-1851
El Manakhly MM, Mohamed HA, Osama MRF, El Hinnawi ME, Soliman KA (1997) Geology and geochemical exploration along the basement-sedimentary contact in South Sinai, Egypt. Final report of expedition No.20.

El Raey M (1998) Framework of integrated coastal area management of the FukaMatrouh area, Egypt, PAP/RAC-37-1995

El-Dien KE (2016) Personal communication with Khalid Ezz El-Dien, director of wells operation and maintenance, North and South Sinai company for water and wastewater.

El-Refeai AA (1992) Water resources of southern Sinai Egypt geomorphological and hydrogeological studies Ph.D. Sci. Thesis, Faculty of Science Cairo University.

Garfunkel Z (1981) Internal structure of the Dead Sea leaky transform (rift) in relation to place kinematics. Tectono-physics 80:81-108

Gheith H, Sultan M (2002) Construction of a hydrologic model for estimating wadi runoff and groundwater recharge in the Eastern Desert, Egypt. J Hydrol 263(1-4):36-55

Greenwood WR, Anderson RE, Fleck RJ, Roberts RJ (1980) Precambrian geologic history and plate tectonic evolution of the Arabian shield: Saudi Arabia Dir. Gen Mineral Resources Bulletin:24-35

Gregory KJ, Walling DE (1973) Drainage basin form and process. John Wiley and Sons, New York

Gupta M, Srivastava PK (2010) Integrating GIS and remote sensing for identification of groundwater potential zones in the hilly terrain of Pavagarh, Gujarat, Indian. Water Int 35:233-245

Hagget P (1956) Locational analysis in human geography. Edward Arnold Ltd, London

Himida IH (1997) Water resources of Wadi Watir. Internal report, Desert Research Center (In Arabic)

Horton RE (1945) Erosional development of stream and their drainage basins. Geol Soc Am Bull 56:275-330

Hussien HM, Kehew AE, Aggour T, Korany E, Abotalib AZ, Hassanein A, Morsy S (2017) An integrated approach for identification of potential aquifer zones in structurally controlled terrain: Wadi Qena basin, Egypt. Catena 149:73-85

IFRC (International Federation of Red Crescent and Red Cross), (2010). Egypt: flash floods. Published report available online at www.ifrc.org/docs/appeals/10/ MDREG009dfr.pdf. Accessed 15 May 2018

IPCC (Intergovernmental Panel on Climate Change), (2014). Climate change: impacts, adaptation and vulnerability. Fifth Assessment report (AR5). http:// www.ipcc.ch/. Accessed 15 Oct 2018

Isawi H, El-Sayed MH, Eissa M, Shouakar-Stash O, Shawky H, Mottaleb MSA (2016) Integrated geochemistry, isotopes, and geostatistical techniques to investigate groundwater sources and salinization origin in the Sharm ELSheikh Area, South Sinai, Egypt. Water Air Soil Pollut 227(151):1-23

Jenson SK, Domingue JO (1988) Extracting topographic structure from digital elevation model data for geographic information system analysis. Photogramm Eng Remote Sens 54:1593-1600

Magesh N, Chandrasekar N, Soundranayagam J (2011) Morpho-metric evaluation of Papanasam and Manimuthar watersheds, parts of Western Ghats, Tirunelveli district, Tamil Nadu, India: a GIS approach. Environ Earth Sci 64: 373-381

Mart Y (1982) Incipient spreading center in the Gulf of Elat, northern Red Sea. Earth Planet Sci Lett 60:117-126

Mart Y, Hall JK (1984) Structural trends in the northern Red Sea. J Geophys Res 89:11352-11364

Maus S, Barckhausen U, Berkenbosch H, Bournas N, Brozena J, Childers V, Dostaler F, Fairhead JD, Finn C, von Frese RRB, Gaina C, Golynsky S, Kucks R, Lühr H, Milligan P, Mogren S, Müller D, Olesen O, Pilkington M, Saltus R, Schreckenberger B, Thébault E, Caratori Tontini F (2009) EMAG2: A 2-arcminute resolution earth magnetic anomaly grid compiled from satellite, airborne and marine magnetic measurements. Geochem Geophys Geosyst 10:Q08005. https://doi.org/10.1029/2009GC002471

Maus S, Sazonova T, Hemant K, Fairhead JD, Ravat D (2007) National geophysical data center candidate for the world digital magnetic anomaly map. Geochem Geophys Geosyst 8:Q06017. https://doi.org/10.1029/ 2007GC001643

Melton MN (1957) An analysis of the relations among elements of climate surface properties and geomorphology. Project NR 389-042 Tech. Rept. II, Columbia University, and Dept. of Geology, On Geog., R., Branch, New York.

Meshref WM, Refai E, Abdel-Hady YE, Sharaf El-Din SM (1992) Rift tectonics of the southern Gulf of Suez: gravity and magnetic contribution. Proceedings of the 
Eleventh Petroleum Exploration Conference, the Egyptian General Petroleum Corporation (EGPC), Cairo, Egypt, 7-10 Nov., 1992, Exploration 1.

Milewski A, Sultan M, Yan E, Becker R, Abdeldayem A, Soliman F, Abdel Gelil K (2009) A remote sensing solution for estimating runoff and recharge in arid environments. J Hydrol 373:1-14

Miller VG (1953) A quantitative geomorphic study of the drainage basin characteristics in the Clinch Mountain area, Virginia and Tennessee. Colombia University, Geology Dept., Project NR389-042, Technical Report No. 3

Moawad MB, Abdel Aziz AO, Mamtimin B (2016) Flash floods in the Sahara: a case study for the 28 January 2013 flood in Qena, Egypt. Geomat Nat Haz Risk 7(1):215-236

Mohamed L, Sultan M, Ahmed M, Zaki A, Sauck W, Soliman F, Abouelmagd A (2015) Structural controls on groundwater flow in basement terrains: geophysical, remote sensing, and field investigations in Sinai. Surv Geophys 36(5):717-742

Mwaniki MW, Moeller MS, Schellmann GA (2015) Comparison of Landsat 8 (OLI) and Landsat $7(\mathrm{ETM}+)$ in mapping geology and visualizing lineaments: a case study of central region Kenya. 36th International Symposium on Remote Sensing of Environment, The International Archives of the Photogrammetry Remote Sensing and Spatial Information Sciences, XL-7/W3.

Naim G (1995) Floods of upper Egypt governorates Egyptian geological survey and mining authority. Cairo, Egypt.

ORNL DAAC. (2017). Spatial Data Access Tool (SDAT). ORNL DAAC, Oak Ridge, Tennessee, USA. Accessed 09/10/2018. https://doi.org/10.3334/ORNLDAAC/ 1388

Ramirez JA (2000) Prediction and modeling of flood hydrology and hydraulics, chapter 11, of inland flood hazards: human, riparian and aquatic communities Eds. Ellen Wohle; Cambridge University Press.

Reid AB, Allsop JM, Granser H, Millett AJ, Somerton IW (1990) Magnetic interpretation in three dimensions using Euler Deconvolution. Geophysics 55: 80-91

Ross CW, Prihodko L, Anchang J, Kumar S, Ji W, Hanan NP (2018) Global hydrologic soil groups (HYSOGs250m) for curve number-based runoff modeling. ORNL DAAC, Oak Ridge, Tennessee, USA. https://doi.org/10.3334/ ORNLDAAC/1566

Said IR, Ahmed AA (1990) Pattern of the main tectonic trends from remote geophysics, geological structures and satellite imagery, Central Eastern Desert, Egypt. Int J Remote Sens 11(4):669-683

Said R (1962) The geology of Egypt. Elsevier, Amsterdam and New York

Salas JD, Rajagopalan B, Saito L, Brown C (2012) Special section on climate change and water resources: climate nonstationary and water resources management. J Water Resour Plan Manag 138:385-388

Saleh S, Saleh A (2012) Stress analysis and tectonic trends of southern Sinai Peninsula, using potential field data analysis and anisotropy technique. Cent Eur J Geosci 4(3):448-464

Schumm SA (1956) Evolution of drainage systems and slopes in badlands at Perth Amboy, New Jersey. Bull Geol Soc Am 67:597-646

Sherief Y (2008) Flash floods and their effects on the development in El-Qaá plain area in south Sinai, Egypt, a study in applied geomorphology using GIS and remote sensing. PhD Dissertation, Mainz University, Germany.

Siegal BS, Gillespie AR (1980) Remote sensing in geology. Academic Press, New York

Smith KG (1958a) Standard for grading texture of topography. Am J Sociol 5(298): $655-668$

Smith KG (1958b) Erosional processes and landforms in Badlands National Monument, South Dakota. Geol Soc Am Bull 69:975-1008

Spector A, Grant FS (1970) Statistical models for interpreting aeromagnetic data. Geophysics 35(2):293-302

Stern RJ (1994) Arc assembly and continental collision in the Neoproterozoic East African Orogen: implications for the consolidation of Gondwanaland. Annu Rev Earth Planet Sci 22:319-351

Strahler AN (1953) Quantitative analysis of watershed geomorphology. Trans Am Geophys Union 38:913-920

Strahler AN (1964) Quantitative geomorphology of drainage basins and channel networks. In Chow, V.T. (ed.) Handbook of Applied Hydrology, McGraw-Hill, New York, 439-476.

Sultan M, Sturchio NC, Gheith H, Hady YA, El Anbeawy M (2000) Chemical and isotopic constraints on the origin of Wadi El-Tarfa ground water, Eastern Desert, Egypt. Ground Water 38(5):743-751

Sultan M, Wagdy A, Manocha N, Sauck W, Gelil KA, Youssef AF, Becker R, Milewski A, El Alfy Z, Jones C (2008) An integrated approach for identifying aquifers in transcurrent fault systems: the Najd shear system of the Arabian Nubian shield. J Hydrol 349(3):475-488

Thomas J, Joseph S, Thrivikramji K, Abe G, Kannan N (2012) Morphometrical analysis of two tropical mountain river basins of contrasting environmental settings, the southern Western Ghats, India. Environ Earth Sci 66(8):23532366

UNESCO (1979) Map of the world distribution of arid regions: map at scale 1: 25,000,000 with explanatory note. MAB Technical Notes 7. UNESCO, Paris9231015486.

USDA-SCS (1972) Hydrology. Section 4, soil conservation service, national engineering handbook. U.S. Department of Agriculture-Soil Conservation Service: Washington, DC.

USDA-SCS (1986) Urban hydrology for small watersheds. Soil conservation service, natural resource conservation service technical release. 55. http:// www.wcc.nrcs.usda.gov/hydro/hydro-tools-models-models-tr55.html

Wheater HS, Mathias SA, Li X (2010) Groundwater modeling in arid and semi-arid areas. Cambridge University Press. ISBN-10: 0521111293; ISBN-13: 9780521111294.

Yousif M, Bubenzer O (2015) Geoinformatics application for assessing the potential of rainwater harvesting in arid regions, El Daba'a area, Northwestern Coast of Egypt. Arab J. Geosci. doi:https://doi.org/10.1007/ s12517-015-1837-0

Yousif M, Henselowsky F, Bubenzer O (2018) Palaeohydrology and its impact on groundwater in arid environments: Gebel Duwi and its vicinities, Eastern Desert, Egypt. CATENA 171:29-43 https://doi.org/10.1016/j.catena.2018.06.028

Yousif M, Sracek O (2016) Integration of geological investigations with multi-GIS data layers for water resources assessment in arid regions: El Ambagi Basin, Eastern Desert, Egypt. Environ Earth Sci 75:1-25. https://doi.org/10.1007/ s12665-016-5456-1

Yousif M, van Gelder R, Bubenzer O (2016) Hydrogeological investigation of shallow aquifers in an arid data-scarce coastal region (El Daba'a, northwestern Egypt). Hydrogeol J 24:159-179. https://doi.org/10.1007/ s10040-015-1308-4

Yuan Y, Xu YS, Arulrajah A (2017) Sustainable measures for mitigation of flooding hazards: a case study in Shanghai, China. Water 9(5):310

\section{Publisher's Note}

Springer Nature remains neutral with regard to jurisdictional claims in published maps and institutional affiliations.

\section{Submit your manuscript to a SpringerOpen ${ }^{\circ}$ journal and benefit from:}

- Convenient online submission

- Rigorous peer review

- Open access: articles freely available online

High visibility within the field

- Retaining the copyright to your article

Submit your next manuscript at $\boldsymbol{\nabla}$ springeropen.com 